\title{
26. MICROSTRUCTURE AND PHYSICAL PROPERTIES OF AMAZON FAN SITES 940 AND 946 FROM WIRELINE, LABORATORY, AND SEDIMENTOLOGIC DATA ${ }^{1}$
}

\author{
John D. Kronen, Jr. ${ }^{2}$
}

\begin{abstract}
The Amazon Fan began to form in the early Miocene and is characterized by a highly meandering channel-levee system. This paper concerns the physical properties of sediments deposited during fourth- $\left(10^{3}\right.$ to $\left.10^{4} \mathrm{yr}\right)$ and fifth-order (instantaneous) events. Core and downhole wireline log data were used to characterize lateral variations from a middle fan site down to a midlower fan site. Scanning electron microscope backscatter (BSE) images were generated from prepared samples obtained from Holes 940A and 946A and analyzed to quantify relative percentages of grains, matrix, and visible pores in sediments, as well as to observe changes in microfabric associated with compaction at each site and from one site to another. Although there is no significant downhole trend in the relative percentages of grains and visible porosity, quantitative analysis of images suggests that there is a progressive reorientation of grains downsection. There appears to be a transitional boundary at $\sim 150$ meters below seafloor (mbsf) at both sites.

Above $150 \mathrm{mbsf}$, variability in relative percentages of grains at both sites is more a function of lithologic variability controlled by changing sedimentary dynamics rather than being strictly a result of increased overburden. At Site 940 , index and wireline $\log$ porosity values agree well, and the difference between index and matrix porosities is $\sim 7 \%-8 \%$. Matrix porosity values generally approach those predicted in situ porosity values. At Site 946 , laboratory index and wireline log porosity values generally agree, but much higher variability is observed in the log data, which suggests the presence of sand-rich intervals, many of which were not recovered in cores. The difference between laboratory index and matrix porosity values at Site 946 was $\sim 5 \%$. Hole 940A compressional wave velocities (wireline log in situ values) closely match with calculated instantaneous compressional wave velocity values derived for terrigenous sediments (silt-clays, turbidites, mudstone-shales) and suggest that the sediments are relatively homogeneous with respect to texture and composition.
\end{abstract}

\section{INTRODUCTION}

It is well known that large deep-sea fans such as the Indus, Bengal, Mississippi, and Amazon Fans are formed by the repetitive and localized input of fluvial sediments controlled by climate change, high-frequency, glacio-eustatic sea-level fluctuations, diapirism/ slumping, and tectonism (Bouma et al., 1985; Kolla and Coumes, 1985). On the Amazon Fan, these sediments were related to a known seafloor morphology across which turbidity currents flowed and subsequently deposited sediment. It is suggested that several depositional environments may be present within fan deposits at any one time and, therefore, an overall understanding of the dynamics involved in the formation of seismic and morphological units needs to be strengthened (Mutti and Normark, 1991). The Amazon Fan grew as a result of the rapid deposition of channel-levee systems that have prograded across medium- to coarse-grained sands deposited at the downstream ends of channels (Flood et al., 1995).

Levee deposits form fining-up sequences predominantly composed of mud with beds of silt and fine sand. Initial results suggest that each major levee complex of the Amazon Fan corresponds to a glacial stage and is capped by a thin interglacial calcareous clay. Within the latest Pleistocene levee complex, major shifts in the position of the active channel have occurred by avulsion on the upper fan approximately every 5-10 k.y. Many individual channel-levee systems show fluctuations in the abundance of overbank silt on even shorter time scales $(0.5-1.5$ k.y.), requiring controls other than sea level on sediment supplied to the fan (Shipboard Scientific Party 1995a). The Amazon Fan, one of the largest modern deep-sea fans,

${ }^{1}$ Flood, R.D., Piper, D.J.W., Klaus, A., and Peterson, L.C. (Eds.), 1997. Proc. ODP, Sci. Results, 155: College Station, TX (Ocean Drilling Program).

${ }^{2}$ Department of Geology and Geophysics, School of Ocean and Earth Science and Technology, University of Hawaii at Manoa, Honolulu, HI 96822 U.S.A.

jkronen@soest.hawaii.edu began to form in the early Miocene and is characterized by a highly meandering channel-levee system (Damuth and Flood, 1985). The mid-Cretaceous to Quaternary Foz de Amazonas sedimentary basin underlies the Amazon River mouth and the upper Amazon Fan. The fan extends downslope in a north-northeasterly direction from the shelf break to abyssal depths $(4700 \mathrm{~m})$ as far as $700 \mathrm{~km}$ and has a surface area of $\sim 350,000 \mathrm{~km}^{2}$. It has an elongate radial morphology, a maximum thickness of 4-5 km (Castro et al., 1978), and a total volume of $\sim 700,000 \mathrm{~km}^{3}$.

Mutti and Normark $(1987,1991)$ have defined and categorized the types of events characterizing turbidite sedimentation through a hierarchy based on an approximate time scale for depositional units. At the Amazon Fan (Fig. 1), Leg 155 cored to depths encompassing a hierarchy of third-order $\left(10^{4}\right.$ to $\left.10^{5} \mathrm{yr}\right)$ deposits, probably through at least one turbidite stage. This paper concerns the physical properties of sediments deposited during fourth- and fifth-order events. Fourth-order $\left(10^{3}\right.$ to $\left.10^{4} \mathrm{yr}\right)$ deposits were described as the turbidite facies association and component substages characterized as highfrequency changes in depositional and erosional processes of poorly understood origin. Fifth-order (instantaneous events) deposits were described as beds, and their features were characterized by "normal" small-scale erosion and deposition.

Despite the difficulty involved in describing sedimentation processes, Mutti and Normark (1991) recognized five primary elements in turbidite systems. Of these, overbank deposits, comprising the channel and levees on both sides, can be laterally extensive and typically form the largest part of most modern turbidite systems (in area and volume). Normark (1978) realized that they increase in size as the size of the turbidite system increases.

Muds and mudstones comprise greater than half of the world's known sedimentary section, yet relatively little is known about their origin and depositional history (Potter et al., 1980; Reynolds and Gorsline, 1991). Difficulty in visually discerning their individual components through traditional optical microscopic methods can 

of 17 sites. Modified from Flood et al., 1995; modified from Damuth et al., 1988, and Manley and Flood, 1988.
Figure 1. Map of the Amazon Fan showing the location

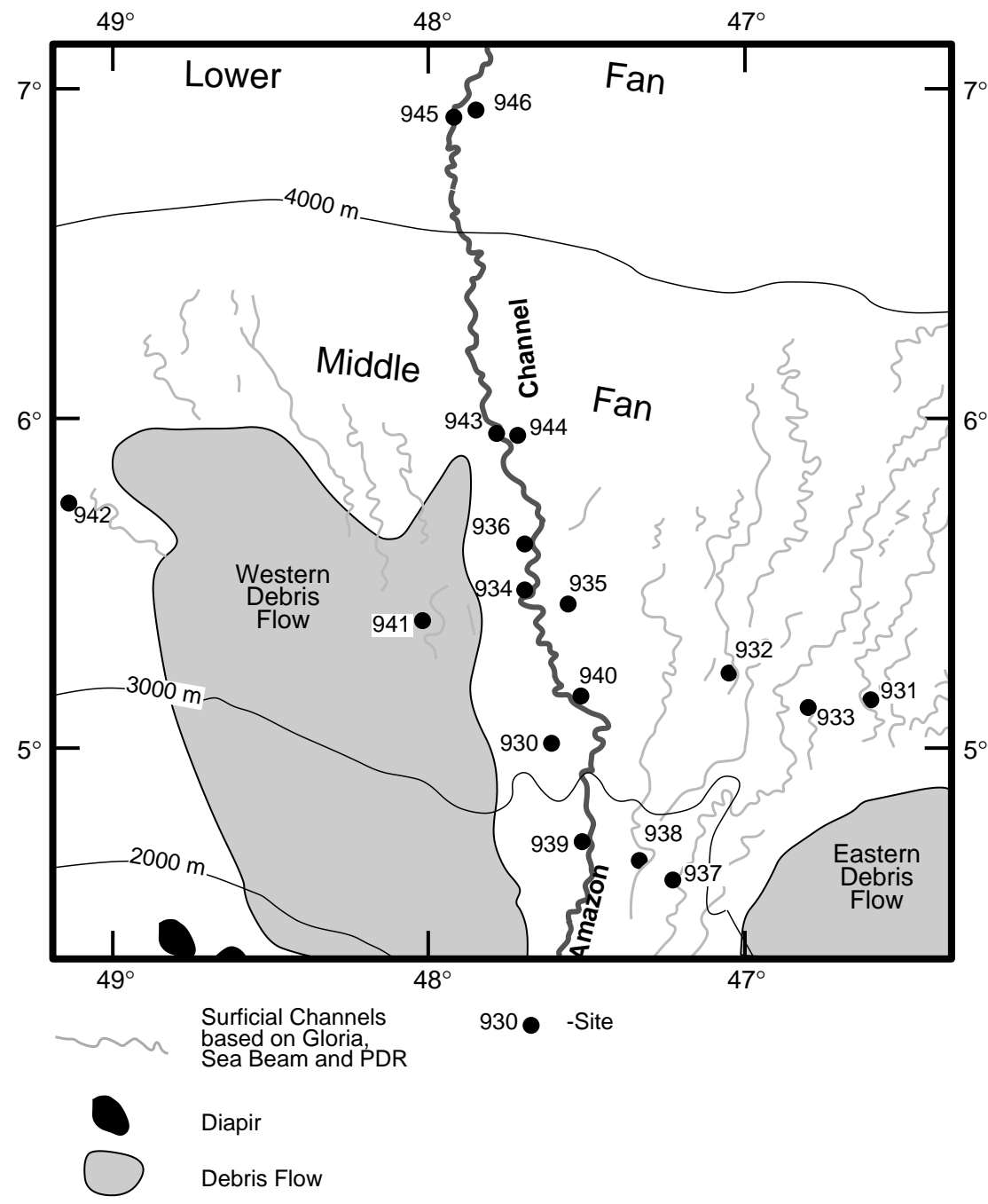

Lithology

now be minimized with the advent of improved backscatter electron detectors (BSE) capable of providing high-resolution images. BSE imaging of polished samples yields micrographs at approximately the same scale obtained from traditional optical microscopy, yet also provides clear definition of platy minerals, higher resolution of clays, nearly two-dimensional images, and a more meaningful representation of microfabrics and structures (Reynolds and Gorsline, 1991). The purpose of this study is to examine the microstructure/fabric of sediment samples obtained from Sites 940 and 946 and to relate observations in derived matrix porosity using discrete laboratory (index properties) porosity values to changes in physical properties measured downhole. Porosity in the predominantly matrix-supported mud-rich deposits of the Amazon Fan appears to vary because of changes in grain content and increasing overburden pressure (compaction). The primary objectives are to (1) correlate core and downhole wireline log data, (2) obtain information that will characterize lateral variations from a middle fan site down to a mid-lower fan site, and (3) make observations in changes of grain size and shape, percent grains to matrix to visible porosity (identified in digital scanning electron microscope [SEM] images), and other physical properties identified from core sample microstructural image and wireline log data. Digital image data acquired from these samples are used to characterize visible pore space, matrix, and grains. These data, when correlated and compared with log and laboratory data, allow for a better determination of the nature of sedimentary sections from intervals of poor core recovery.
Shipboard lithologic descriptions for Sites 940 and 946 reveal a fair amount of variability based on bed thicknesses, identification of silty and sandy intervals, color banding, and bioturbation. For the most part, however, there is not a lot of variability in composition. Levee deposits cored and recovered at Site 940 (Fig. 1) consist of mud to silty mud, ranging from color-banded and bioturbated muds to nonbanded muds, with interbedded laminae and beds of silt and very fine sand. Bulk X-ray diffraction and smear-slide analyses reveal $\sim 3 \%$ carbonate content in the mud. Beds of silt and fine sand vary in thickness and frequency and are often thickest near the base of a subunit. Site 940 has confirmed that the proportions of deposited silt and sand to mud fluctuate considerably within a single levee, but that each levee growth phase is represented by an overall fining-upward sequence (Shipboard Scientific Party, 1995b). Three depositional "packages" are recognized, based on a lithologic description from Hole 940A (Fig. 2). The oldest package (Subunits IIJ-IIG) is a thinning- and fining-upward sequence. The second package comprises Subunit IIF, with two intervals of abundant silty turbidites alternating with intervals of bioturbated mud with fewer silts. The third package comprises Subunits IIB to IIE and has two intervals of abundant turbidite silts (more abundant than in Subunit IIF), together with long intervals of bioturbated and color-banded sediment. These siltier intervals in each package tend to show a thinning-upward and in some cases fining-upward sequence, except for the basal 5-10 m, which tends 


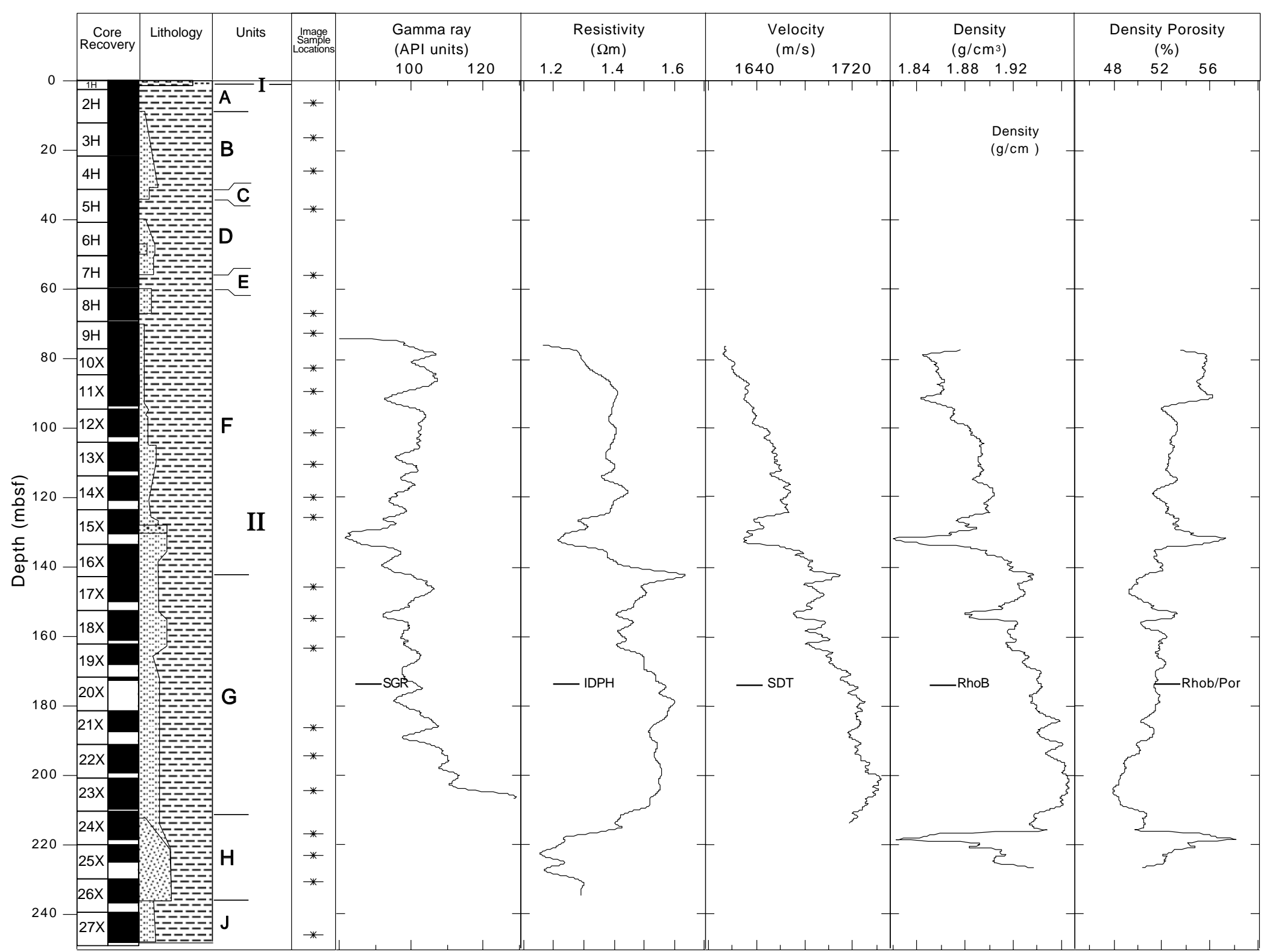

Figure 2. Composite section for Site 940 showing core recovery, simplified summary of lithology, division of lithostratigraphic units, depths of image sample locations, and smoothed wireline logging data. Spectral gamma ray $=$ SGR; deep phasor induction resistivity = IDPH; long-spacing sonic velocity $=$ SDT; bulk density $=$ RhoB; and density porosity $=$ RhoB $/$ Por. 


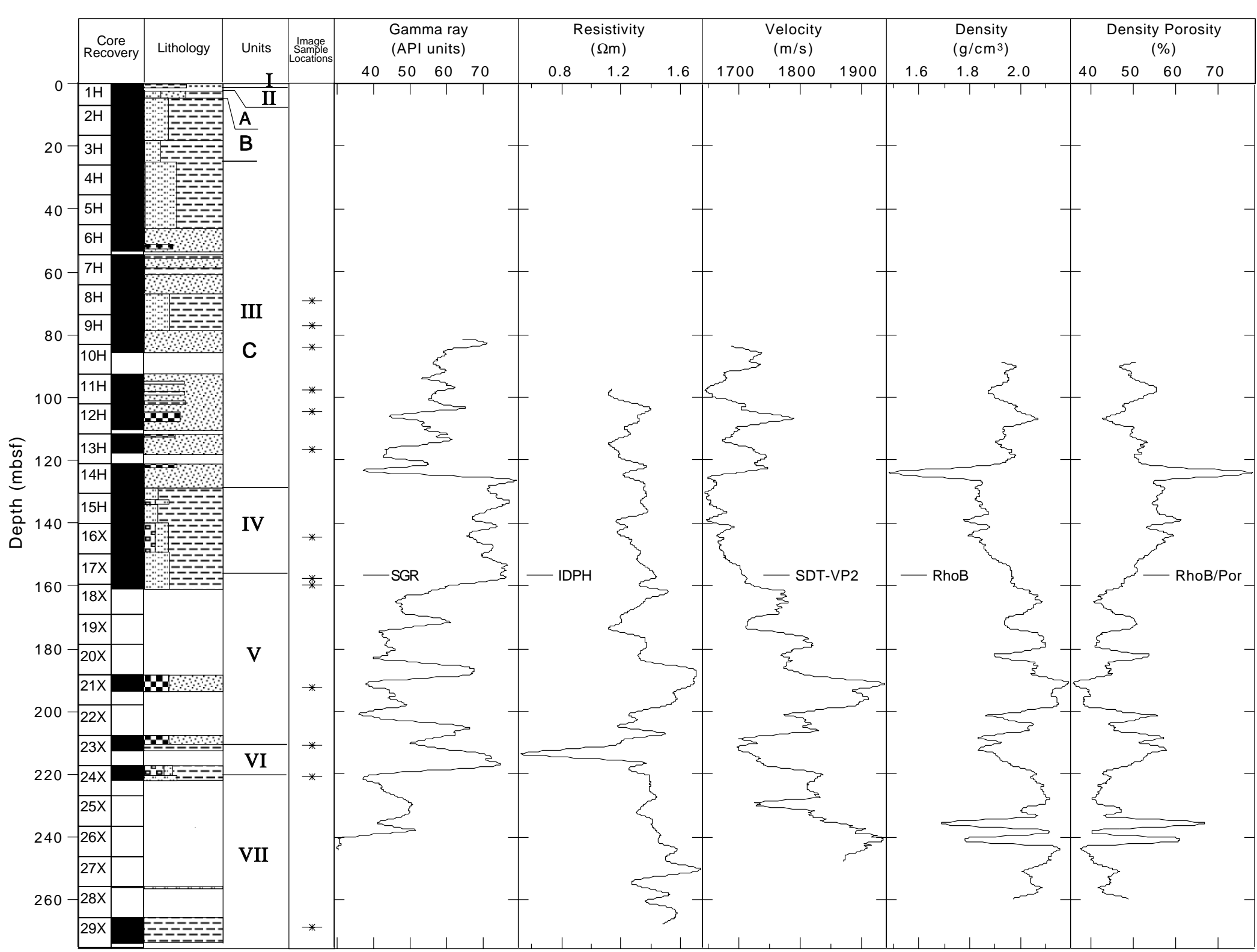

Figure 3. Composite section for Site 946 showing core recovery, simplified summary of lithology, division of lithostratigraphic units, depths of image sample locations, and smoothed wireline logging data. Spectral gamma ray $=$ SGR; deep phasor induction resistivity = IDPH; long-spacing sonic velocity = SDT-VP2; bulk density = RhoB; and density porosity = RhoB Por. Wireline data have been smoothed with a 2.5 -m window. 
to be coarsening and thickening upward (Shipboard Scientific Party, 1995b).

Levee deposits were cored and recovered at Site 946 (Fig. 1). Unit III consists of mud to silty mud with higher percentages of interbedded sand (Fig. 3). Recovery was only $48 \%$ (Shipboard Scientific Party, 1995c). Some intervals recovered mud with abundant beds of silt and sand, commonly with erosional bases, and there is a general trend towards thicker beds in the lower part of the intervals. Unit IV consists of mud with laminae and thin beds of silt, and it was divided into subunits on the basis of the frequency of silt laminae and beds (Shipboard Scientific Party, 1995c). Subunit IVA has abundant silt beds and laminae. Subunit IVB comprises mottled mud, locally with color banding, whereas Subunit IVC (to base of unit) consists of colorbanded mud with frequent beds and laminae of silt.

\section{METHODS AND TECHNIQUES Log Data}

Downhole measurements obtained from wireline logging tools were reprocessed and the depth corrected by the Borehole Research Group (BRG) at Lamont Doherty Earth Observatory (LDEO). For this paper, the data have been smoothed using a running average box filter with a $2.5-\mathrm{m}$ window (Figs. 2, 3). The original data are measured at $0.15-\mathrm{m}$ intervals, although the tools average over intervals of $\sim 1 \mathrm{~m}$. Smoothing reduces noise (and possibly instrument drift) and helps in comparing log values to values of the same parameters obtained from discrete shipboard measurements on core recovered. The use of "smoothed" average values further reduces the possibility of a large disagreement between downhole log and index property values resulting from depth offsets between log and recovered core.

Gamma-ray values were obtained by the Natural Gamma-Ray Spectrometry Tool (NGT), which measures the natural radioactivity of the formation. Its measurement is also commonly used to estimate the clay or shale content due to the relatively high abundance of potassium (K), uranium (U), and thorium (Th) in clay minerals (Serra, 1984; Schlumberger, 1989). Resistivity values were obtained with the Phasor Dual Induction-Spherically Focused Resistivity Tool (DITE-SFL), which provides measurements of electrical resistivity at different depths of investigation into the formation: deep induction (IDPH), medium induction (IMPH), and shallow spherically focused resistivity signals (SFL; Schlumberger, 1989). The vertical resolution for the IDPH resistivity values is $2 \mathrm{~m}$. Water content and salinity are the most significant factors controlling the electrical resistivity of a formation.

Compressional wave velocities $\left(V_{p}\right)$ were obtained by the digital long-spaced sonic sonde (LSS/SDT). The tool generates an acoustic signal that triggers two receivers spaced at different distances from the signal source. Formation velocity is calculated by dividing the spacing between the two receivers by the delay time measured between the successive triggering of those receivers (Schlumberger, 1989). Formation bulk density values were measured in situ using the Schlumberger lithodensity tool (HLDT); density is calculated by interaction of gamma rays emitted by a radioactive source into the formation. Values of density porosity (porosity derived from HLDT) were derived by using measurements of log bulk density (RhoB, g/ $\mathrm{cm}^{3}$ ), interpolated laboratory grain densities $\left(\mathrm{g} / \mathrm{cm}^{3}\right)$, and the density of seawater $\left(1.146 \mathrm{~g} / \mathrm{cm}^{3}\right)$ using the following equation:

$$
\begin{gathered}
\text { density porosity }(\%)=(\text { grain density }- \text { RhoB }) / \\
(\text { grain density }-1.146)
\end{gathered}
$$

\section{Scanning Electron Microscopy (SEM)}

Unlithified sediment samples $\left(\sim 20 \mathrm{~cm}^{3}\right)$ taken from cores at Sites 940 and 946 were carefully stored in sealed containers immediately after recovery and then refrigerated to maintain fluid saturation and preserve delicate clay fabric. Pore fluids in these saturated samples were successively replaced by Ladd/Spurr ultra-low viscosity epoxy using a stepwise multiple exchange process in a manner so that the sample integrity was preserved (Tribble and Wilkens, 1994). Slices of sediment $2-3 \mathrm{~mm}$ thick were cut so that the imaging surface was perpendicular to the bedding. The sample was first immersed in a solution of $25 \%$ acetone and $75 \%$ water for $48 \mathrm{hr}$. In successive immersions, spaced $48 \mathrm{hr}$ apart, the percentage of acetone gradually increased until the sample was completely saturated in acetone. In the second stage of preparation, the immersion process was repeated with the acetone gradually being replaced until the sample was saturated in epoxy. Samples were then oven cured to harden the epoxy. The result was a sediment sample that had the pore fluid completely replaced by epoxy. The efficacy of the process was confirmed by visual inspection. When the samples were cut and polished, epoxy filled all pore spaces and there was no visual damage to the sediment fabric.

The impregnated sediment samples were then sawn and polished with $0.05-\mu \mathrm{m}$ aluminum polishing compound. The polished surface, a cross section suitable for observation, was coated with a very thin layer of carbon and then mounted for BSE (Pye and Krinsley, 1984) with a Zeiss DSM 962 digital scanning electron microscope. The best images were obtained using a $15-\mathrm{mm}$ working distance. BSE intensity was roughly proportional to the bulk density of the material under the electron beam (usually on the order of $1 \mu \mathrm{m}$ wide). Some of the primary electrons interacted with the sample material being scanned with little energy loss. These electrons were scattered through the material and were eventually reflected back out as backscattered electrons (Reynolds and Gorsline, 1991).

The energy level of electrons is a function of the angle of incidence and the atomic number of the minerals being scanned. With an ideally flat and polished sample surface, the gray-level intensity of the resulting digital image is nearly all a function of atomic number contrast (Reynolds and Gorsline, 1991). Different elements of the sediment may be identified by their relative brightness in BSE: epoxy-filled pores are black, the clayey matrix is dark gray, and grains, mostly quartz, are gray to white, depending on relative densities. In some cases, samples delaminated or separated along parting surfaces upon initial immersion in the fluid exchange process; however, the structure of the sediment within the partings themselves appears reasonably intact. BSE was chosen because the process of sample preparation eliminates sample dehydration associated with secondary electron imaging of fractured surfaces, and because it is most suitable for the quantification of microfabrics. Cracks are occasionally visible in the digital images obtained and are likely due to gas expansion when the recovered cores were brought up to the surface.

Images stored on the Zeiss DSM 962 as digital files are $512 \times 480$ pixels. They are transferred via file transfer protocol (FTP) to a desktop computer (Macintosh). Each image is $\sim 290$ kilobytes. In this work, we have stored images at five magnifications $(100 \times, 200 \times$, $500 \times, 100 \times$, and $2000 \times$ ). Using image analysis software (i.e., NIH Image), we can quantify through an interactive process relative percentages of grains, matrix, and visible pore space. Separations of different gray-scale levels $(0-255)$ are chosen generally as the midpoints between maxima that represent grains, matrix, and pores. An example of a gray-scale image and its histogram of gray levels is presented in Figure 4. By generating a gray-level histogram showing the distribution of relative intensities in a sample (Fig. 4B), we can determine the threshold that divides grains from matrix and visible pores, and then visible pores from matrix and grains. Thresholds taken from histograms are used to convert gray-scale images into binary (black and white) images. Everything within a band of gray-level values is turned to black, and all other pixels are turned to white. A binary image can then be generated by using this threshold value as the limit to isolate grains or visible pores. The relative percent of grains or visible pores is then determined. By isolating the grain threshold, an unprocessed image (Fig. 4A) is shown as a binary image of grains (Fig. 5A). The original image has been "cleaned" by a filter that reduces noise 
A

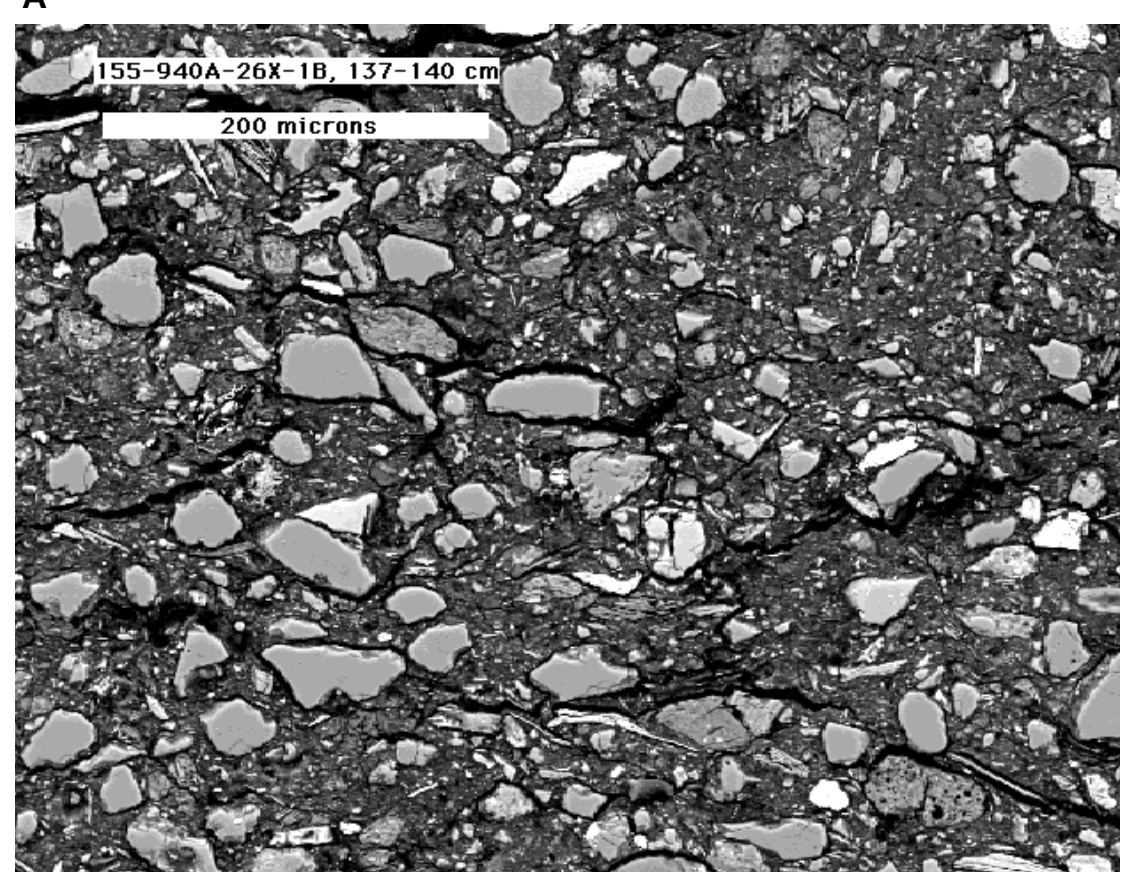

B

Figure 4. A. Example of a BSE gray-scale image, Sample 155-940A-26X-1B, 137-140 cm (230.67 mbsf). B. Example of a BSE gray-scale image histogram illustrating the distribution of gray levels used in the quantification of images.

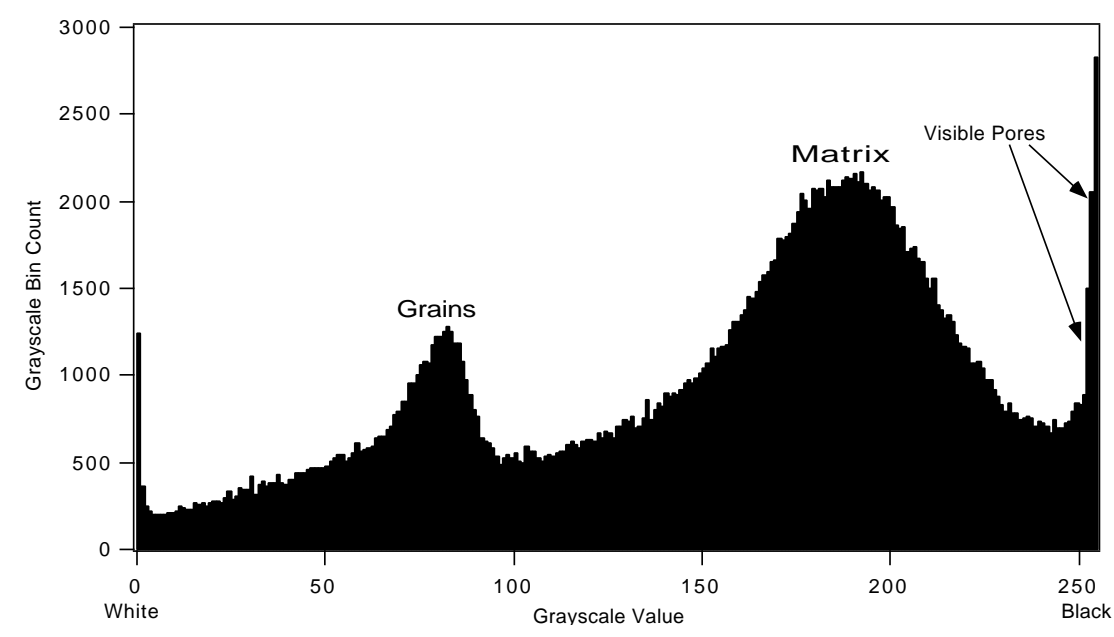

to remove small points. Noise reduction filtering is illustrated by Figures $5 \mathrm{~B}$ and $5 \mathrm{C}$, which show binary images of raw and "cleaned" visible pores. The raw threshold binary image contains numerous small black areas that are not identifiable as pores in the original image. Our analyses show that repeated assessments of gray-scale boundaries and volumes of components by different analysts on the same samples showed repeatability usually within $1 \%$ and never exceeding $2 \%$. Each sample was imaged at three random localities (areas A, B, C) on the sample. We also acknowledge that these three areas do not fully describe the entire sample unless it is truly homogeneous. To get an idea of the variability involved, all three values as well as the averages, are presented in Table 1. The reader will also be able to look at these and more images on CD-ROM in the back pocket of this volume. Table 2 lists the file names for these images.

The reason we only do three random areas per sample is time and money, as SEM time is expensive and the analysis of 36 samples at three areas at several magnifications and three components post-collection involves over 300 gray-scale images (and many more binary images). Also, even if we were to count the entire area of a sample, we do not know how representative an $\sim 1-2 \mathrm{~cm}$ slice of core is of sediment above and below it. In some sense, it is remarkable that we see as much consistency in calculated values as we do. Relative percentages of grains and visible pore space were determined at all three locations from the $200 \times$ magnification images (Table 1). An average value was then derived from the three values obtained at a specific magnification.

\section{Calculation of Matrix Porosities}

Once relative percentages of grains, matrix, and visible pore space are quantified from image analysis, matrix porosity (the porosity within the fine-grained portion, usually clayey matrix, of a sediment) can then be determined by using the following equation:

$$
\begin{gathered}
\text { Matrix porosity }(\%)=[\text { porosity }(\%)-\text { visible pores }(\%)] / \\
{[100-\text { grains }(\%)-\text { visible pores }(\%)]}
\end{gathered}
$$


A

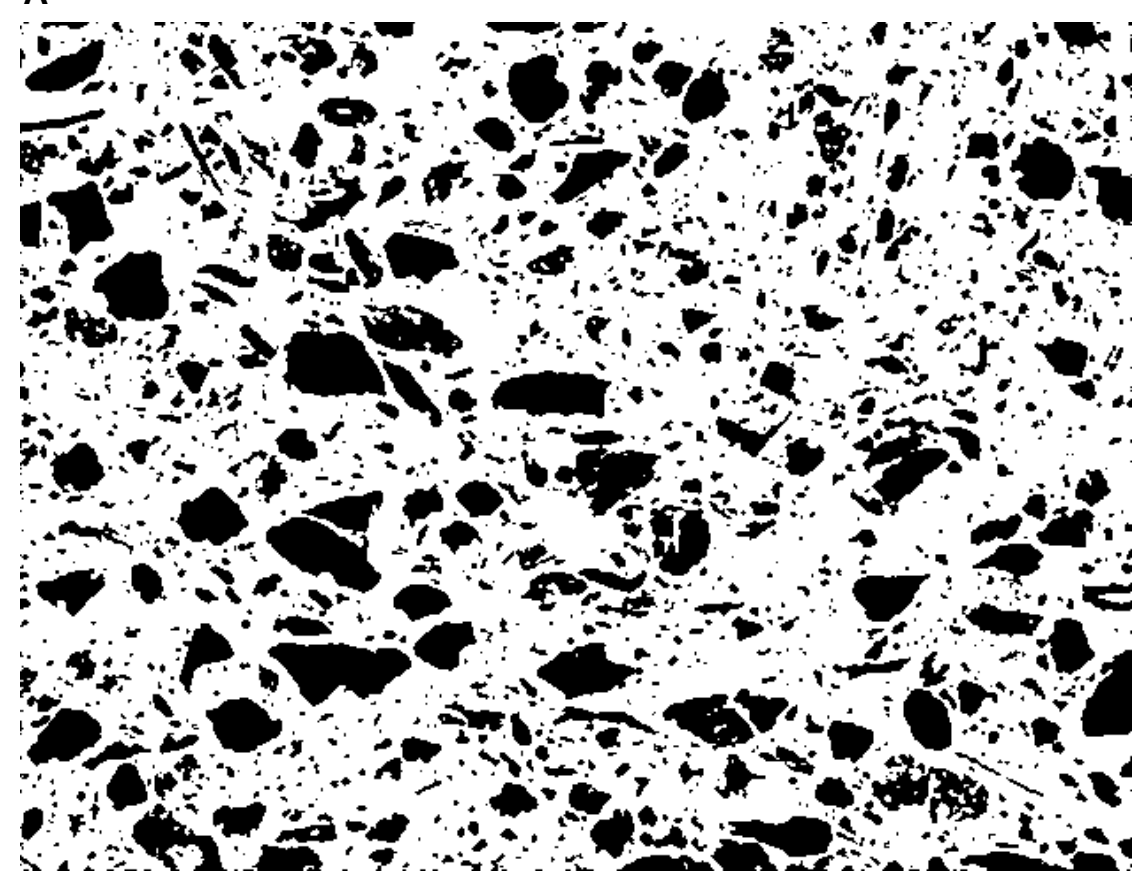

B

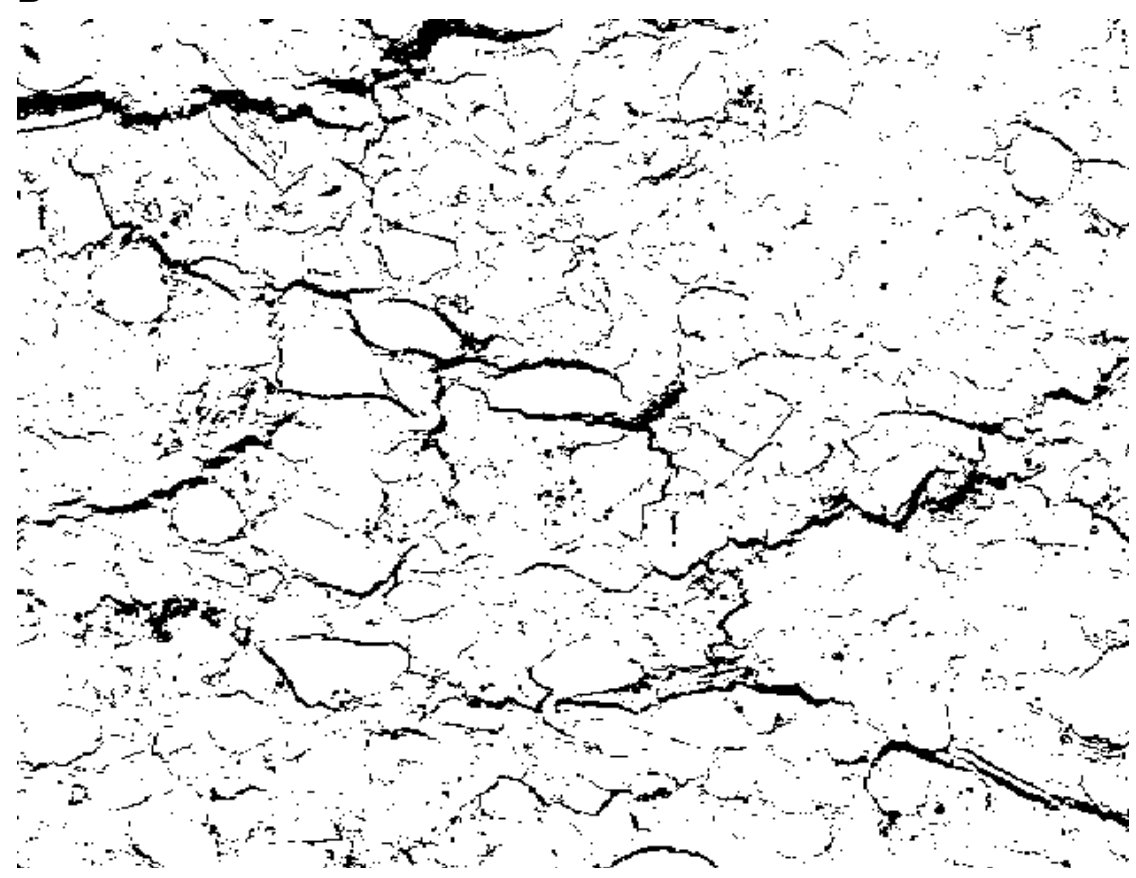

Figure 5. A. Binary image of grains, Sample 155-940A26X-1B, 137-140 cm (230.67 mbsf). B. Raw binary image of pores, Sample 155-940A-26X-1B, 137-140 $\mathrm{cm}(230.67 \mathrm{mbsf})$.

Discrete laboratory porosity values were obtained from shipboard index properties measured adjacent to the microfabric samples (Shipboard Scientific Party, 1995b).

\section{RESULTS AND DISCUSSION}

\section{Microfabric Image Processing}

Backscattered images were generated from prepared samples obtained from Holes 940A and 946A and analyzed to quantify relative percentages of grains, matrix, and visible pores in sediments as well as to observe changes in microfabric that is associated with compaction at each site and from one site to another. In most of the images that we examined in detail ( 23 samples at Hole 940A and 13 at Hole 946A), there are basically three elements (Fig. 6). Relatively large grains $(\mathrm{G})$, appearing uniformly light gray, are surrounded by a very fine-grained to clay size matrix (M) of a darker hue. The matrix contains all of the microporosity. Visible pore space (V) appears black in the images when filled with the low density epoxy.

\section{Site 940}

Site 940 is located mid-fan on the flank of the eastern levee of the Amazon Channel $\sim 3 \mathrm{~km}$ from the levee crest at a water depth of 3191.4 meters below seafloor (mbsf; Fig. 1). Hole 940A penetrated to $248.6 \mathrm{mbsf}$ and core recovery was $84 \%$. It is a high sedimentation 
Figure 5 (continued). C. "Cleaned" binary image of pores, Sample 155-940A-26X-1B, 137-140 cm (230.67 mbsf). The original binary image has been "cleaned" by a filter that reduces noise to remove small points that are not identifiable as visible pores in the original gray-scale images.

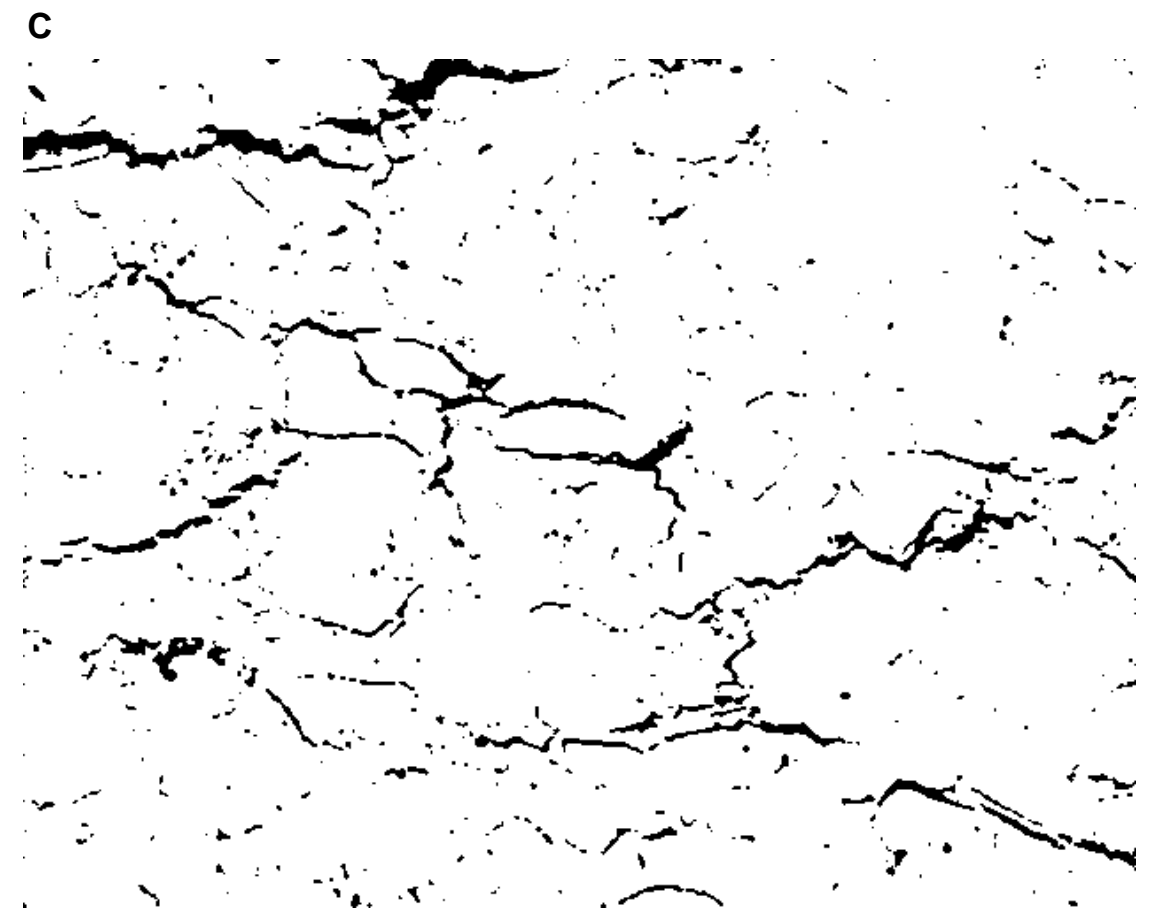

Table 1. Percentages of grains and visible porosity obtained from $200 \times$ BSE images.

\begin{tabular}{|c|c|c|c|c|c|c|c|c|c|}
\hline \multirow{2}{*}{$\begin{array}{l}\text { Core, section, } \\
\text { interval }(\mathrm{cm})\end{array}$} & \multirow{2}{*}{$\begin{array}{l}\text { Depth } \\
\text { (mbsf) }\end{array}$} & \multicolumn{4}{|c|}{ Grains (\%) } & \multicolumn{4}{|c|}{ Visible porosity $(\%)$} \\
\hline & & Area A & Area B & Area $\mathrm{C}$ & Average & Area A & Area B & Area $\mathrm{C}$ & Average \\
\hline \multicolumn{10}{|l|}{ 155-940A- } \\
\hline $2 \mathrm{H}-3,50-52$ & 6.30 & 12.59 & 10.34 & 10.52 & 11.15 & 0.97 & 0.89 & 0.67 & 0.84 \\
\hline $3 \mathrm{H}-3,118-122$ & 16.48 & 8.79 & 10.49 & 9.18 & 9.49 & 0.89 & 2.00 & 1.49 & 1.46 \\
\hline $4 \mathrm{H}-3,100-103$ & 25.80 & 8.65 & 6.74 & 7.27 & 7.55 & 0.43 & 1.19 & 1.28 & 0.97 \\
\hline $5 \mathrm{H}-3,75-76$ & 36.69 & 12.14 & 10.70 & 12.55 & 11.80 & 0.60 & 0.70 & 0.73 & 0.68 \\
\hline $7 \mathrm{H}-5,70-73$ & 56.04 & 12.67 & 14.26 & 12.50 & 13.14 & 0.91 & 1.08 & 1.03 & 1.01 \\
\hline $8 \mathrm{H}-5,135-138$ & 67.15 & 13.63 & 8.19 & 9.94 & 10.52 & 0.94 & 1.08 & 0.73 & 0.92 \\
\hline $9 \mathrm{X}-3,58-61$ & 72.88 & 13.54 & 11.14 & 9.24 & 11.31 & 1.76 & 1.64 & 2.44 & 1.95 \\
\hline $10 X-4,107-110$ & 82.57 & 14.71 & 15.40 & 10.16 & 13.42 & 1.82 & 3.66 & 9.21 & 4.90 \\
\hline $11 \mathrm{X}-4,45-48$ & 89.62 & 12.10 & 12.90 & 11.01 & 12.00 & 0.94 & 3.74 & 2.61 & 2.43 \\
\hline $12 X-5,114-117$ & 101.44 & 13.26 & 5.36 & 15.41 & 14.68 & 2.59 & 2.71 & 1.14 & 2.15 \\
\hline $13 X-5,66-69$ & 110.44 & 19.12 & 12.37 & 14.56 & 15.35 & 6.22 & 2.67 & 1.94 & 3.61 \\
\hline $14 X-5,80-83$ & 119.85 & 7.04 & 13.60 & 10.47 & 10.37 & 1.96 & 0.82 & 1.62 & 1.47 \\
\hline $15 X-2,87-90$ & 125.67 & 15.35 & 11.28 & 11.58 & 12.74 & 1.73 & 2.46 & 2.58 & 2.26 \\
\hline $17 X-3,40-43$ & 146.00 & 11.64 & 17.29 & 16.90 & 15.28 & 2.97 & 2.16 & 2.82 & 2.65 \\
\hline $18 X-3,130-133$ & 155.00 & 13.46 & 9.94 & 14.26 & 12.55 & 1.68 & 0.86 & 0.87 & 1.14 \\
\hline $19 X-2,30-34$ & 163.70 & 16.39 & 10.67 & 13.62 & 13.56 & 2.08 & 1.75 & 4.53 & 2.79 \\
\hline $21 X-4,93-96$ & 186.53 & 13.52 & 11.07 & 9.81 & 11.47 & 2.30 & 1.59 & 0.79 & 1.56 \\
\hline $22 X-3,60-63$ & 194.40 & 9.60 & 11.21 & 11.27 & 10.69 & 1.02 & 1.04 & 2.18 & 1.41 \\
\hline $23 \mathrm{X}-3,137-140$ & 204.40 & 11.85 & 12.40 & 13.52 & 12.59 & 0.48 & 0.79 & 1.90 & 1.06 \\
\hline $24 X-5,80-83$ & 216.80 & 13.82 & 18.48 & 7.51 & 13.27 & 0.63 & 2.05 & 0.87 & 1.18 \\
\hline $25 X-3,59-62$ & 223.12 & 20.64 & 20.40 & 9.70 & 16.91 & 0.60 & 0.96 & 1.08 & 0.88 \\
\hline $26 \mathrm{X}-1,137-140$ & 230.67 & 14.67 & 20.63 & 15.04 & 16.78 & 1.77 & 3.69 & 1.60 & 2.35 \\
\hline $27 X-5,103-106$ & 246.03 & 30.73 & 14.66 & 16.60 & 20.66 & 1.31 & 1.48 & 1.30 & 1.36 \\
\hline \multicolumn{10}{|l|}{$155-946 \mathrm{~A}-$} \\
\hline $8 \mathrm{H}-4,83-86$ & 69.33 & 8.99 & 6.07 & 7.83 & 7.63 & 0.23 & 0.39 & 0.71 & 0.44 \\
\hline $9 \mathrm{H}-3,120-124$ & 77.70 & 11.44 & 8.92 & 10.45 & 10.27 & 0.47 & 0.31 & 0.47 & 0.42 \\
\hline $10 \mathrm{H}-1,127-129$ & 84.27 & 10.90 & 9.07 & 7.91 & 9.29 & 3.04 & 6.51 & 2.34 & 3.96 \\
\hline $11 \mathrm{H}-4,116-119$ & 98.16 & 7.87 & 11.52 & 9.89 & 9.76 & 1.78 & 0.44 & 0.53 & 0.92 \\
\hline $12 \mathrm{H}-3,5-8$ & 105.05 & 7.04 & 16.78 & 17.33 & 13.72 & 0.44 & 3.40 & 7.49 & 3.78 \\
\hline $13 \mathrm{H}-4,97-100$ & 116.97 & 5.97 & 5.43 & 6.10 & 5.83 & 0.61 & 0.48 & 0.65 & 0.58 \\
\hline $16 \mathrm{X}-4,53-56$ & 145.03 & 12.19 & 12.46 & 0.00 & 12.33 & 0.68 & 0.50 & 0.00 & 0.59 \\
\hline $17 X-6,72-75$ & 157.82 & 8.50 & 8.90 & 8.75 & 8.72 & 0.75 & 0.21 & 0.53 & 0.50 \\
\hline $18 \mathrm{X}-1,105-107$ & 160.25 & 11.62 & 8.46 & 11.16 & 10.41 & 2.99 & 1.53 & 1.30 & 1.94 \\
\hline $21 \mathrm{X}-3,137-140$ & 192.57 & 18.18 & 24.51 & 11.36 & 18.02 & 0.65 & 2.17 & 1.36 & 1.39 \\
\hline $23 \mathrm{X}-3,78-80$ & 211.28 & 9.58 & 8.87 & 12.31 & 10.25 & 0.56 & 1.40 & 1.67 & 1.21 \\
\hline $24 \mathrm{X}-3,95-98$ & 221.05 & 11.34 & 13.03 & 13.56 & 12.64 & 0.80 & 1.68 & 11.10 & 4.53 \\
\hline $29 X-3,60-62$ & 269.00 & 12.02 & 12.74 & 12.38 & 12.38 & 2.33 & 1.16 & 1.83 & 1.79 \\
\hline
\end{tabular}

rate site, where biostratigraphic data indicate an age younger than 40 $\mathrm{ka}$ at total depth (Shipboard Scientific Party, 1995b). The largest amount of detrital input comes from the Amazon Channel. BSE images generally displayed silty turbidite muds with siliciclastic grains, predominantly quartz, floating in a clay-rich matrix. No grain-tograin contacts were observed in any of the images.
Sample 155-940A-2H-3, 50-52 cm (6.3 mbsf), predominantly consists of subangular to subrounded grains in a matrix of clays and other platy minerals such as muscovite and biotite (Fig. 7). "Matrix" is considered any material less than $\sim 10 \mu \mathrm{m}$. Note that the orientation and arrangement of grains do not display any planar features and that the grains are poorly sorted and encompass a wide range in apparent 
Table 2. Listing of $200 \times$ and $500 \times$ BSE images located on CD-ROM (see back pocket).

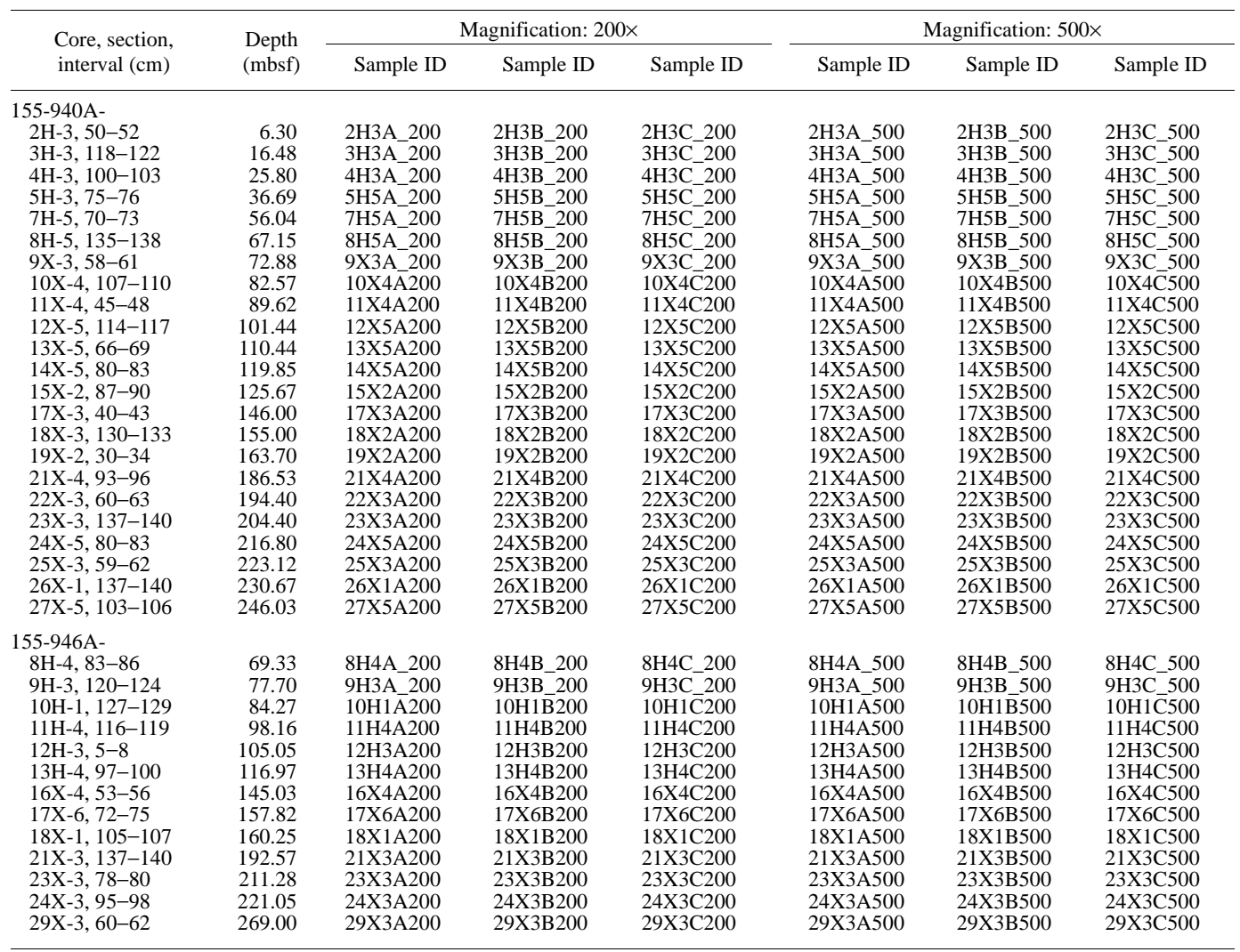

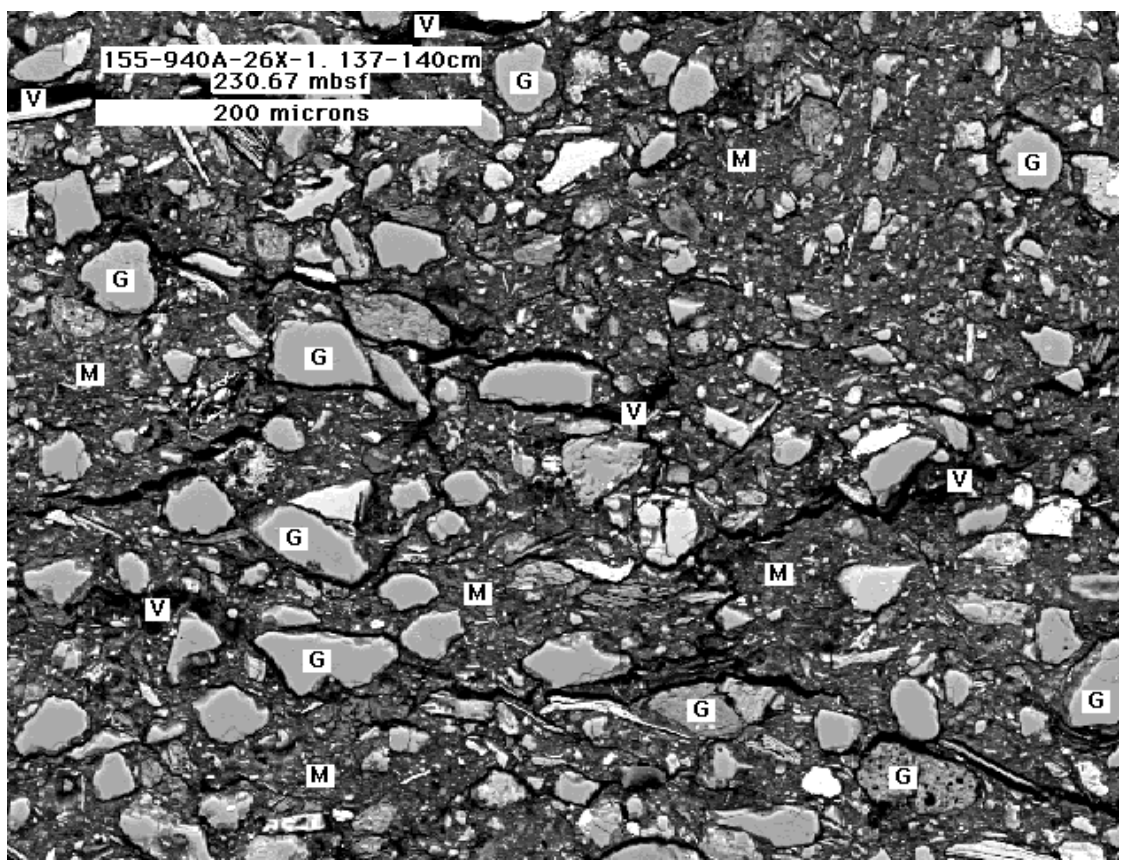

Figure 6. BSE image of Sample 155-940A-26X-1B, $137-140 \mathrm{~cm}$ (230.67 mbsf), illustrates the three elements whose abundances were quantified using image analysis techniques. Examples of each element are identified as follows: $\mathrm{G}=$ grains; $\mathrm{M}=$ matrix; and $\mathrm{V}=$ visible pore spaces. grain sizes from 10 to $40 \mu \mathrm{m}$. Visible pore space obtained from three images ranges from $0.67 \%$ to $0.97 \%$ for an average value of $0.84 \%$. Grain percentages range from $10.3 \%$ to $12.6 \%$ for an average value of $11.2 \%$. Most imaging sites on a given sample are within $1 \mathrm{~cm}$ of each other, yet there can be a considerable amount of variability in the values obtained (see Table 1). This variability reveals that physical properties can change upsection or downsection not only at the centimeter to meter scale, but also at the submillimeter scale even in a setting characterized by high sedimentation rates.

Sample 155-940A-5H-5, 75-76 cm (36.69 mbsf), also consists of subangular to subrounded grains floating in a matrix of clays and other platy minerals similar to $155-940 \mathrm{~A}-2 \mathrm{H}-3,50-52 \mathrm{~cm}(6.3 \mathrm{mbsf})$, yet it displays a faint planar fabric (Fig. 8A, B). Flat- or planarshaped grains are oriented parallel to bedding and can help to define 
Figure 7. BSE image of Sample 155-940A-2H-3A, $50-52 \mathrm{~cm}$ (6.3 mbsf), showing subangular to subrounded grains floating in a matrix of clays and other platy minerals.

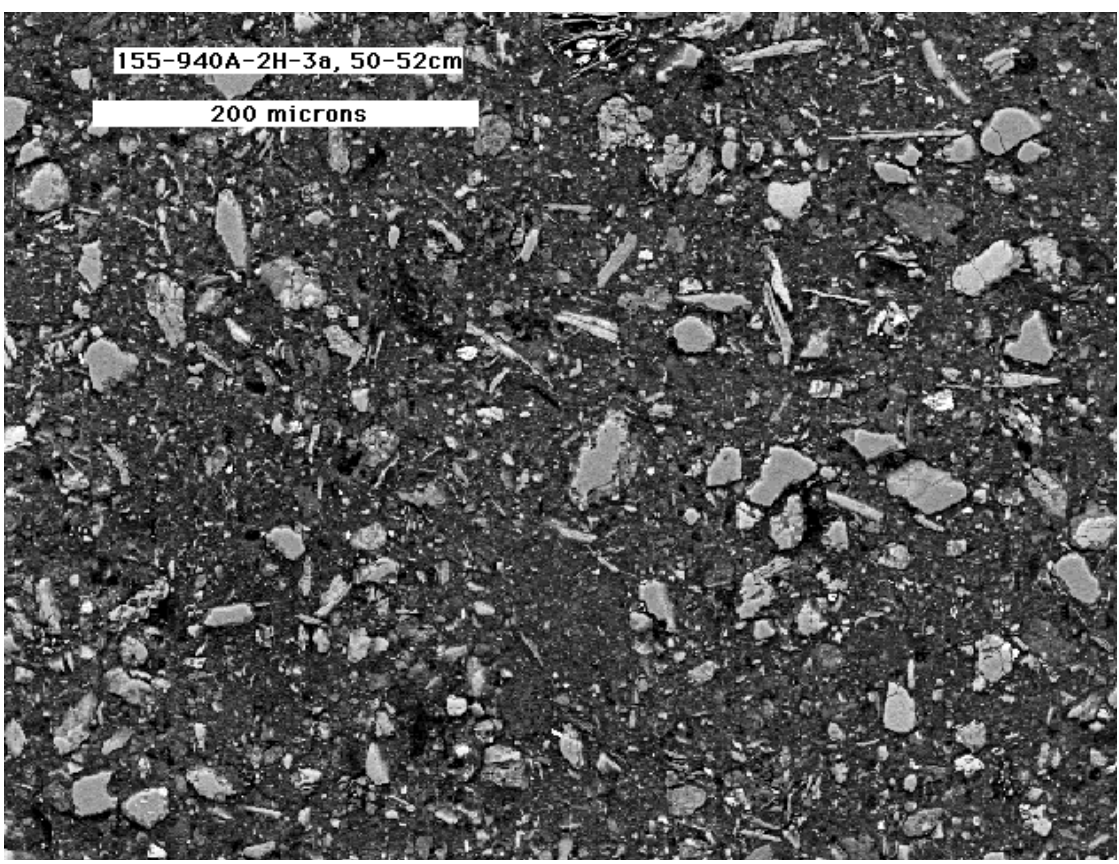

bedding. The difference in bedding character seen here compared to Sample 155-940A-2H-3, 50-52 cm (6.3 mbsf), may be due to different primary sedimentation dynamics rather than to orientation of grains by compaction. The dark elements in the image represent large visible pore spaces that may represent conduits or pathways for the transmission of pore fluids. Arrangement of pores appears to parallel bedding.

In Sample 155-940A-8H-5, 135-138 cm (67.15 mbsf), a well-defined planar fabric is shown by the boundary between two beds/laminae with distinctly different relative percentages of grains and matrix. Flat or planar-shaped grains have become oriented parallel to bedding (Fig. 9A). The dark elements in the image represent large visible pore spaces that may represent conduits or pathways for transmission of pore fluids, or possibly depressurization voids. Whether these are "primary" (i.e., formed during or shortly after deposition) or "secondary" (i.e., developed prior to lithification) (see Wartel et al., 1991) fabric elements is not clear. Sample 155-940A-11X-4, 45-48 cm (89.62 mbsf; Fig. 9B), has a homogeneous appearance and consists of non-oriented subangular to subrounded grains floating in a matrix similar to Sample 155-940A-2H-3, 50-52 cm (6.3 mbsf). Grain percentages range from $11 \%$ to $12.9 \%$ for an average value of $12 \%$; however, visible pore space obtained from three images ranges from $0.94 \%$ to $3.7 \%$ for a higher average value of $2.4 \%$. The dark elements represent visible pore spaces as observed in Sample 155940A-8H-5, 135-138 cm (67.15 mbsf). Note the development of cracks associated with round pore spaces.

Sample 155-940A-14X-5, 80-83 cm (119.85 mbsf), consists of subangular to subrounded grains floating in a matrix and displaying a faint orientation of grains (Fig. 9C). Grain percentages range from $7 \%$ to $13.6 \%$ for an average value of $10.4 \%$. Visible pore space obtained from three images ranges from $0.82 \%$ to $2 \%$ for an average value of $1.5 \%$. The large visible pore spaces and associated cracks, represented by dark elements, are well established. Studies have determined that although sediment microtexture in clays can be an effective barrier to fluid transport, open fractures provide conduits for rapid transport (Ferrell et al., 1989; Ferrell and Carpenter, 1991). Flat or planar-shaped grains are oriented parallel to bedding. Similar to Sample 155-940A-8H-5, 135-138 cm (67.15 mbsf), a well-defined boundary between two beds/laminae with distinctly different relative percentages of grains and matrix is shown in image 155-940A-14X$5,80-83 \mathrm{~cm}$ (119.85 mbsf; Fig. 9D). The U-shape contact may be due to erosion or to bioturbation (cf. Reynolds and Gorsline, 1991). Samples 155-940A-15X-2, 87-90 cm (125.6 mbsf), and 17X-3, 40$43 \mathrm{~cm}$ (146 mbsf), consist of subangular to subrounded grains in a matrix of clays (Fig. 10A, B). Note the homogeneous appearance and that the orientation and arrangement of grains reveals no lamination. Grains are poorly sorted and encompass a wide range in apparent grain sizes from 10 to $30 \mu \mathrm{m}$. Visible pore space obtained from image analysis has an average value of $2.65 \%$. Grain percentages average $15.3 \%$.

Sample 155-940A-21X-4, 93-96 cm (186.53 mbsf), has a fabric similar to $155-940 \mathrm{~A}-17 \mathrm{X}-3,40-43 \mathrm{~cm}$ (146 mbsf), yet displays a faint planar fabric as indicated by flat- or planar-shaped grains that are oriented parallel to bedding (Fig. 10C). This may be a result of burial compaction. Visible pore space obtained from image analysis has an average value of $1.6 \%$. Grain percentages are lower than in Sample 155-940A-17X-3, 40-43 cm (146 mbsf), with an average value of $11.47 \%$. In Sample 155-940A-24X-5, 80-83 cm (216.8 mbsf), a well-defined planar fabric is shown by rectangular to flat grains that are oriented parallel to bedding (Fig. 11A). The dark elements in the image represent visible pore spaces mainly represented by cracks or the parting of matrix around grains (see binary; Fig. 11B). The effects of burial compaction appear to become more established, as indicated by a well-oriented pattern in grains and a lower percentage of matrix. Samples 155-940A-25X-3, 59-62 cm (223.12 mbsf), 26X-1, 137-140 cm (230.67 mbsf), and 27X-5, 103-106 cm (246 mbsf), all display a relatively similar character (Fig. 12A-C). The images reveal that the sediments are generally coarser grained and that the grains are oriented parallel to bedding. Visible pore space is of two kinds, cracks and partings around grains and along grains parallel to bedding, and small to large circular pores within the matrix. Grains are typically coarser, encompass a wide range in grain sizes from 10 to $70 \mu \mathrm{m}$, and represent $17 \%$ to $21 \%$ of the sediment (Fig. 13). Spaces surrounding grains are most likely artifacts of the "decompaction" of matrix during retrieval.

\section{Site 946}

Site 946 is located on the lower fan near the transition from the middle to lower Amazon Fan, on the flank of the eastern levee of the Amazon Channel, $\sim 1.2 \mathrm{~km}$ from the levee crest at a water depth of 4100.1 mbsf. Hole 946A penetrated to $275 \mathrm{mbsf}$, and core recovery 
A

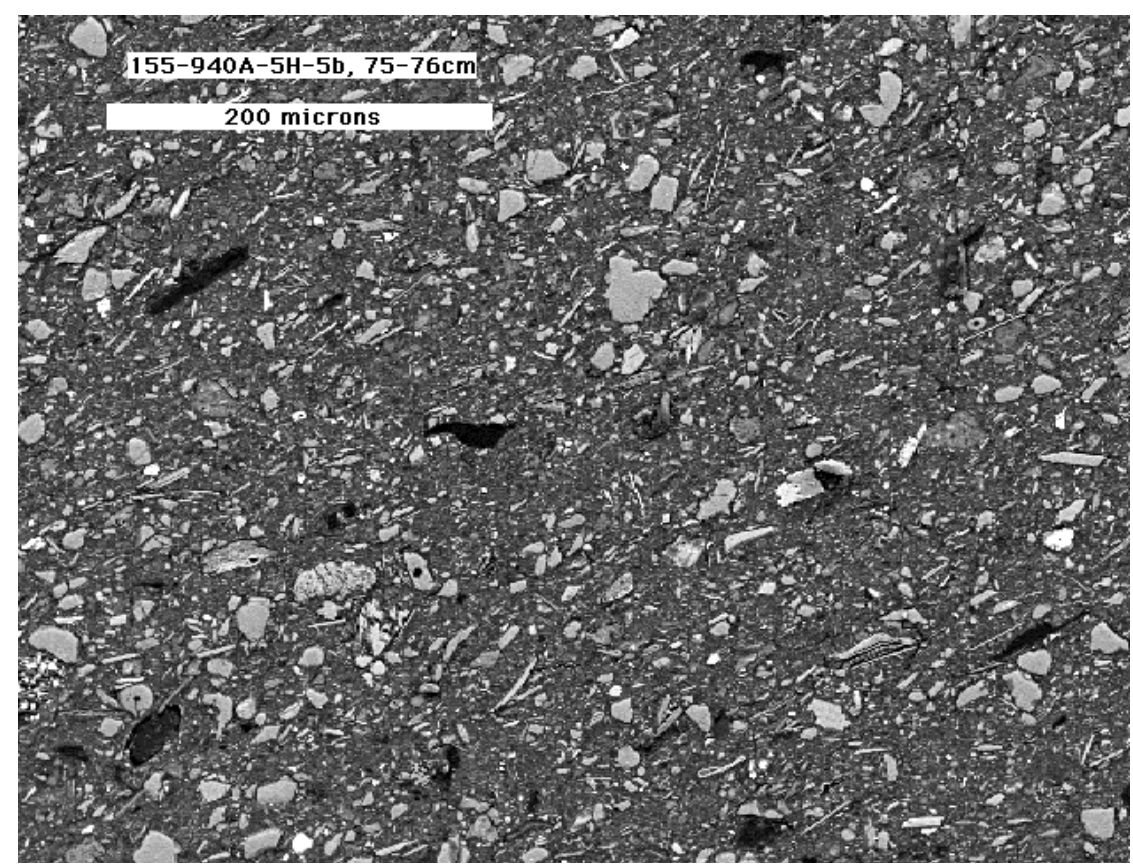

B

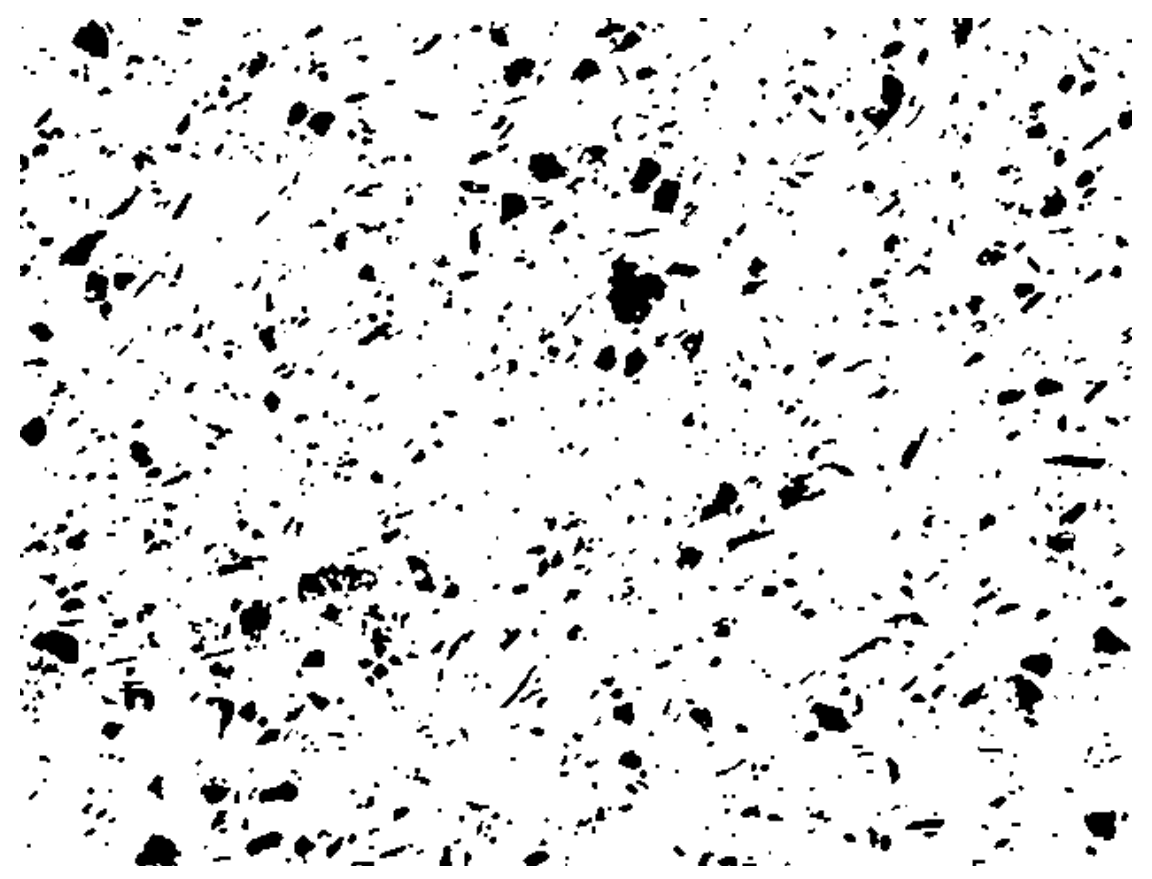

Figure 8. A. BSE image of Sample 155-940A-5H-5B, $75-76 \mathrm{~cm}$ (36.69 mbsf), showing faint planar fabric (dipping to left). B. Binary image of grains for Sample 155-940A-5H-5B, 75-76 cm (36.69 mbsf).

was only $62 \%$. Biostratigraphic data indicate an age of middle Pleistocene at total depth (Shipboard Scientific Party, 1995c). The largest amount of detrital input comes from the Amazon Channel. As in the BSE digital images described above for Hole 940A, these images generally displayed silty turbidite muds with siliciclastic grains, predominantly quartz, floating in a clay-rich matrix. No grain-to-grain contacts were observed in any of the images.

Samples 155-946A-8H-4, 83-86 cm (69.33 mbsf), 9H-3, 120$124 \mathrm{~cm}$ (77.7 mbsf), and 12H-3, 5-8 cm (105.05 mbsf; Fig. 14A-C), show fabric arrangements comparable to those observed in Samples $155-940 \mathrm{~A}-8 \mathrm{H}-5,135-138 \mathrm{~cm}$ (67.15 mbsf), and 11X-4, 45-48 cm (89.62 mbsf; Figs. 9, 10), which are at similar depths below the seafloor. They appear to be negligibly affected by compaction. One no- ticeable difference is the generally finer grains found in these sediments, ranging from 10 to $30 \mu \mathrm{m}$. Samples 155-946A-17X-6, 72-75 cm (157.82 mbsf), 18X-1, 105-107 cm (160.25 mbsf), 21X-3, 137$140 \mathrm{~cm}$ (192.57 mbsf), and 24X-3, 95-98 cm (221.05 mbsf; Fig. 15A-D), also show comparable fabric arrangements influenced by burial compaction to those observed in Samples 155-940A-17X-3, 40-43 cm (146 mbsf), 21X-4, 93-96 cm (186.53 mbsf), 24X-5, 80$83 \mathrm{~cm}$ (216.8 mbsf), and 25X-3, 59-62 cm (223.12 mbsf; Figs. 1417A), also at similar depths below the seafloor. Again, one noticeable difference is the generally finer apparent grain sizes found in these sediments, ranging from 10 to $50 \mu \mathrm{m}$.

Sample 155-946A-29X-3, 60-62 cm (269 mbsf), shows evidence of the further effects of compaction as grains are oriented parallel to 
A

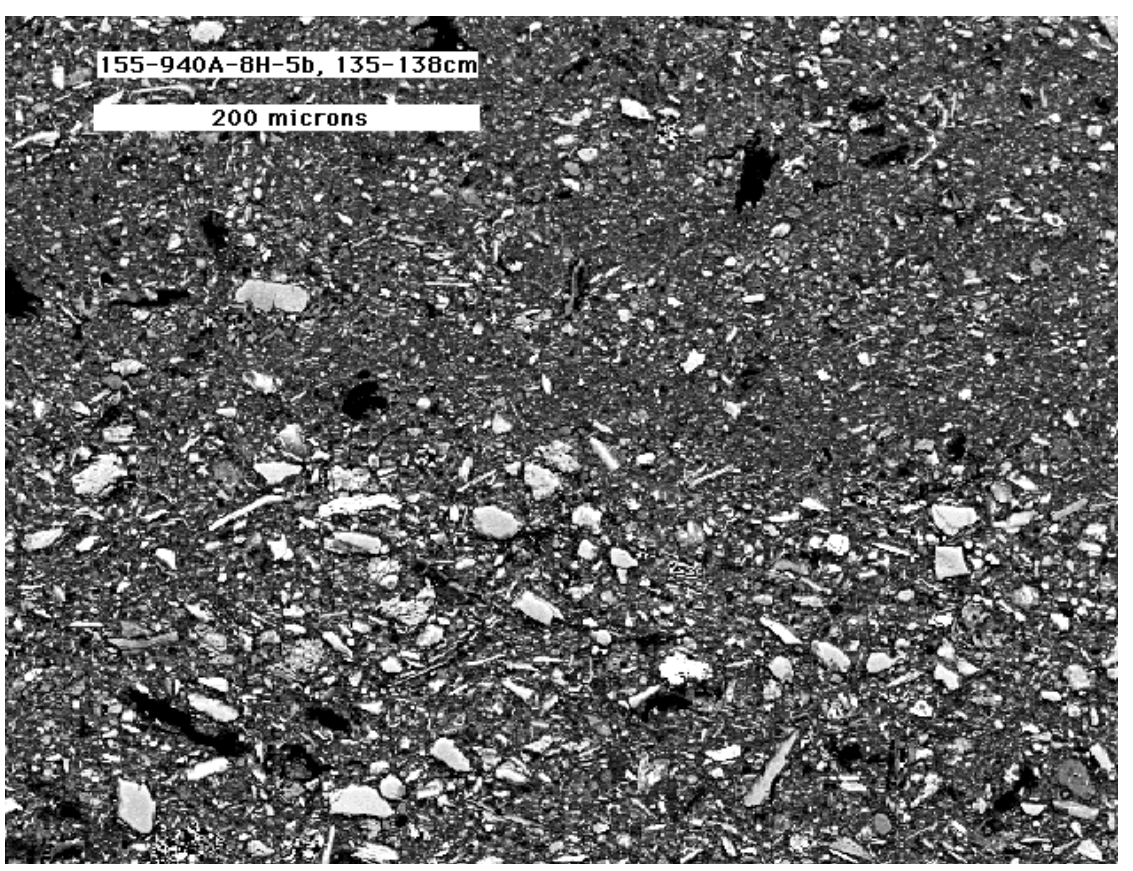

B

Figure 9. A. BSE image of Sample 155-940A-8H5B, 135-138 cm (67.15 mbsf), displays a welldefined planar fabric as shown by the boundary between two beds/laminae with distinctly different relative percentages of grains and matrix. B. BSE image of Sample 155-940A-11X-4C, 45-48 cm (89.62 mbsf), has a homogeneous appearance and consists of non-oriented subangular to subrounded grains floating in a matrix similar to Sample 155940A 2H-3A, 50-52 cm (6.3 mbsf).

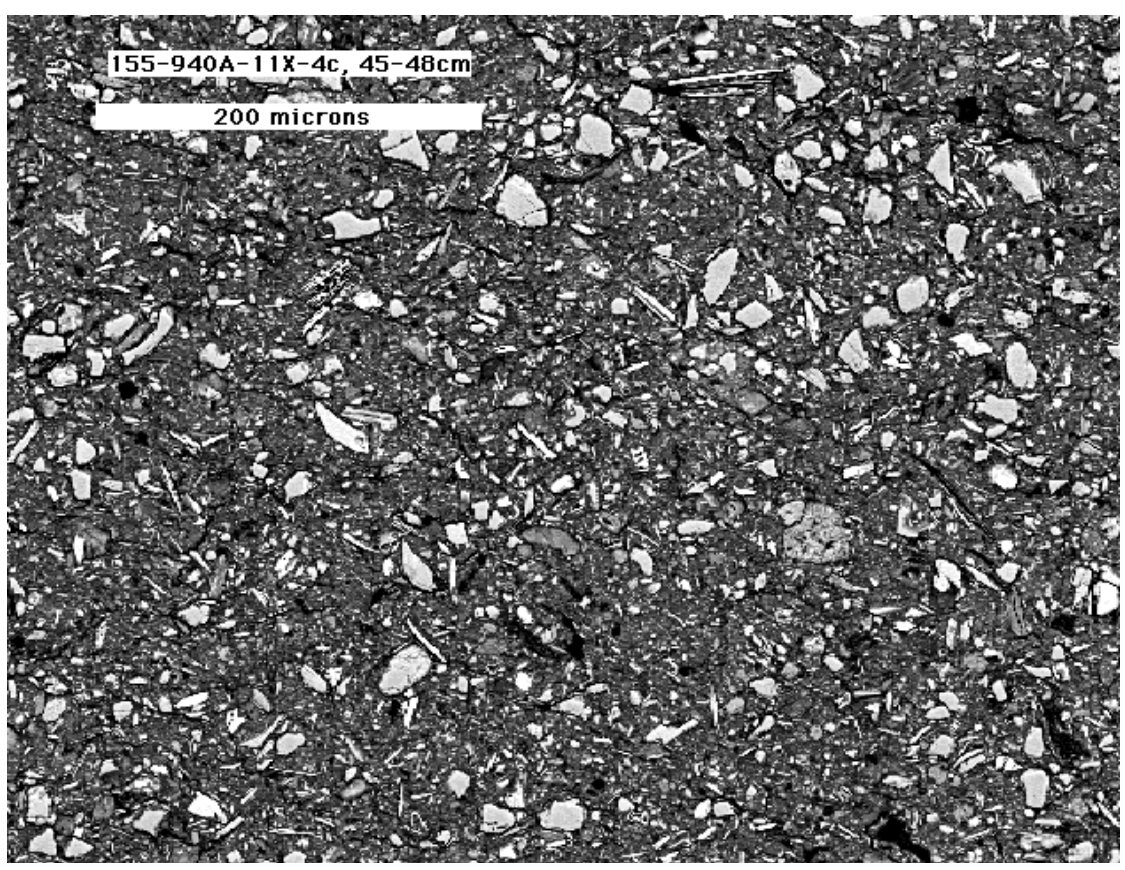

bedding and cracks, suggesting that grains have been realigned (Fig. 16). Visible porosity within the matrix appears to be low, but this is difficult to estimate because of extensively developed cracks. These cracks may have been caused by expansion of the core and/or poor sample preservation.

\section{Microfabric Trends Downhole}

Although there is no significant downhole trend in the relative percentages of grains and visible porosity at Sites 940 and 946 (Fig. 13), direct visual observation of images suggests that there is a progressive reorientation of grains downsection. There appears to be a transitional boundary at $\sim 150 \mathrm{mbsf}$ at both sites, with increases in grain percentages and the degree of grain reorientation most notable below this depth. There is also a general decrease in density porosity below 150-200 mbsf (Fig. 3); however; this decrease may be due to an increase in sand-rich lithology within that interval. A downhole transition in physical properties should be expected with increasing overburden pressure. During normal compaction, porosity present as visible pores and as microporosity within the matrix should decrease with depth. In the absence of any significant diagenetic processes (i.e., dissolution of grains), the relative percentages of matrix and grains should increase as porosity decreases (Tribble and Wilkens, 1994). Although visible pore space values are low to begin with, there is no appreciable reduction in values observed. The variability in the relative percentages of grains at both sites is more a function of 
C

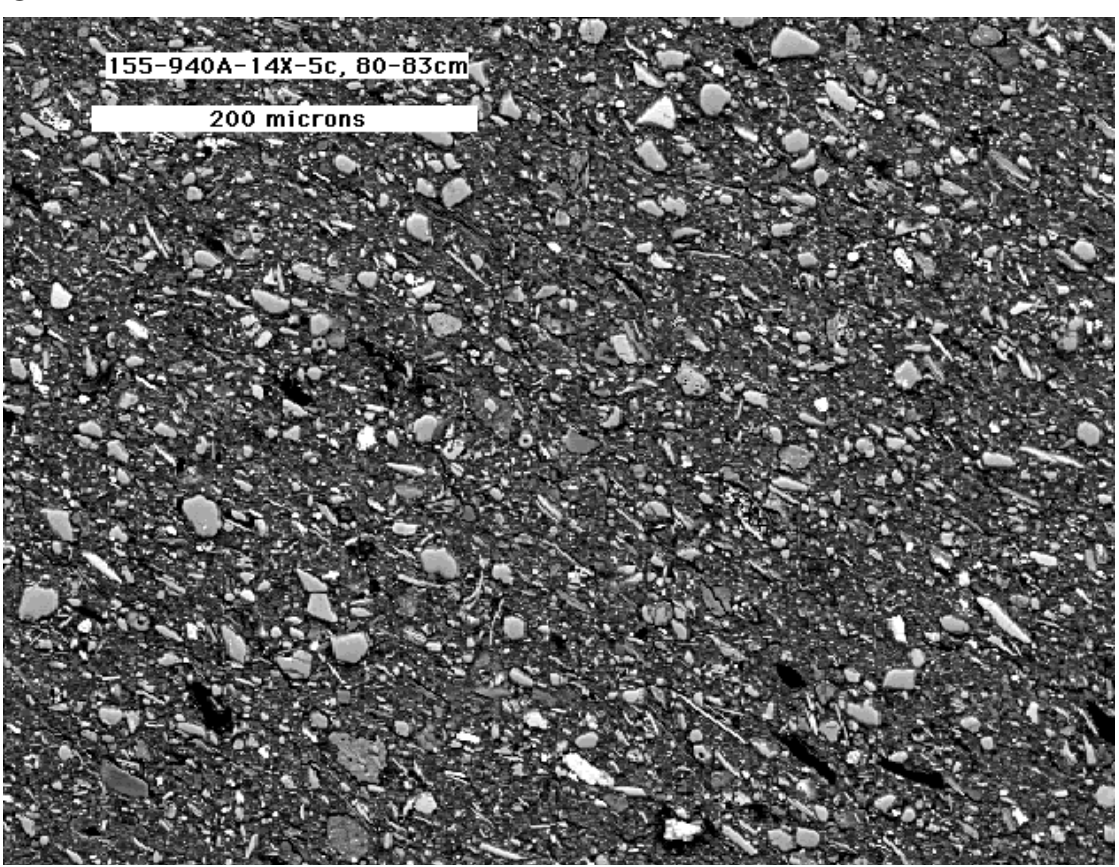

D

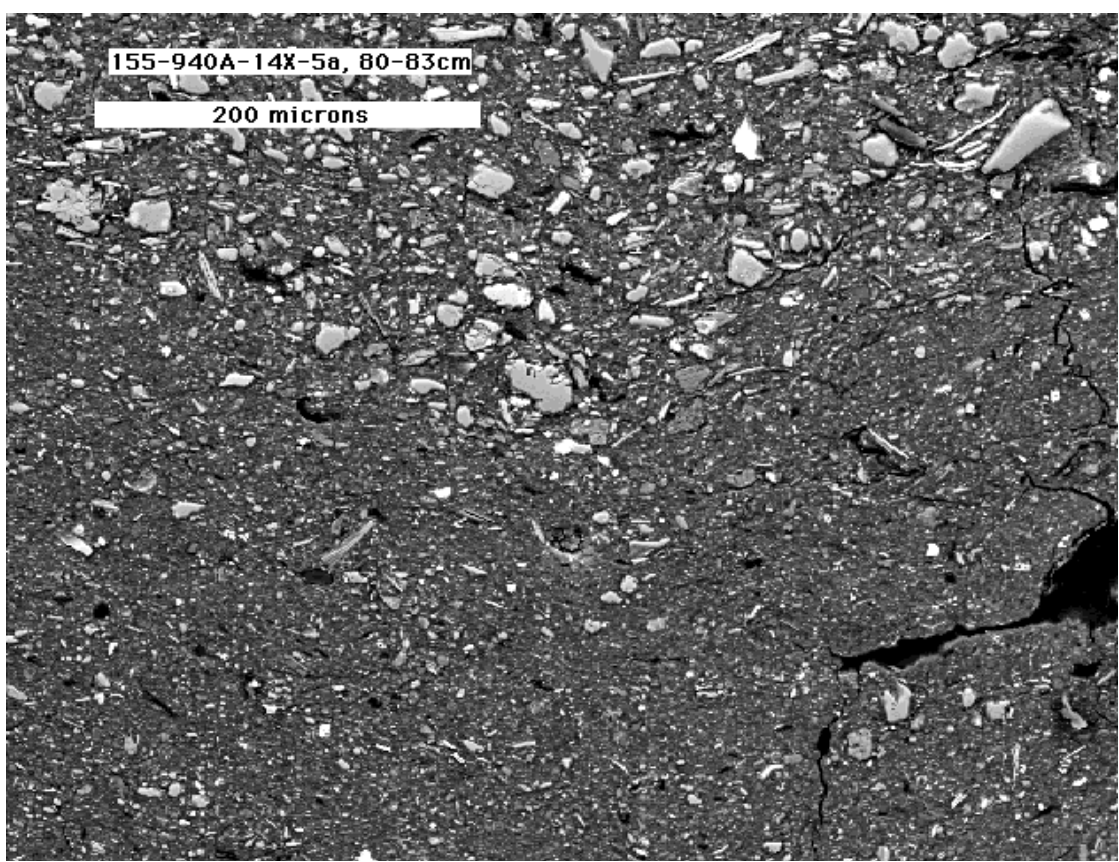

Figure 9 (continued). C. BSE image of Sample 155940A-14X-5C, 80-83 cm (119.85 mbsf), shows subangular to subrounded grains floating in a matrix and displaying a faint orientation of grains. The large visible pore spaces and associated cracks are well established. D. BSE image of Sample 155-940A-14X-5A, 80-83 cm (119.85 mbsf), shows a U-shaped contact possibly formed by erosion or bioturbation on a well-defined boundary between two beds/laminae with distinctly different relative percentages of grains and matrix can be seen.

lithologic variability controlled by changing sedimentary dynamics rather than being strictly a result of increased overburden.

Laboratory index porosity values obtained from Holes 940A and 946A appear to be in good agreement with wireline log-derived values (Fig. 17). At Hole 940A, they are in very good agreement, and at Hole $946 \mathrm{~A}$, there is a general background agreement, but log porosity displays a much higher variability even when the data have been smoothed with a 5-m window. According to index properties, most of the loss in porosity occurs within the first 20 to $30 \mathrm{~m}$. This is unlike what Hamilton's (1976) predicted in situ porosity curve for deep sea terrigenous sediments suggests. Hamilton's in situ values were derived from laboratory values obtained from Deep Sea Drilling Project (DSDP) Leg 23, Site 222, located on the Indus Fan. Index porosity and wireline log values rapidly diverge from Hamilton's curve to values lower by $\sim 10 \%-15 \%$. Matrix porosities, derived from image analysis and index properties, are in better agreement with Hamilton's curve, suggesting a very mud-rich environment, but not accounting for the presence of silt and sand in the sediment.

At Site 940, index and wireline log porosity values agree well. The difference between index and matrix porosities is $\sim 7 \%-8 \%$. Matrix porosity values generally approach those of Hamilton's (1976) predicted in situ porosity (vs. depth) curve (Fig. 17). Lower values observed for matrix porosity may be attributable to the composition and texture of the matrix. A finer or more clay-rich matrix will tend to have higher porosity and perhaps similar values to Hamilton's predicted curve for deep sea terrigenous sediments. Sediments were de- 
A

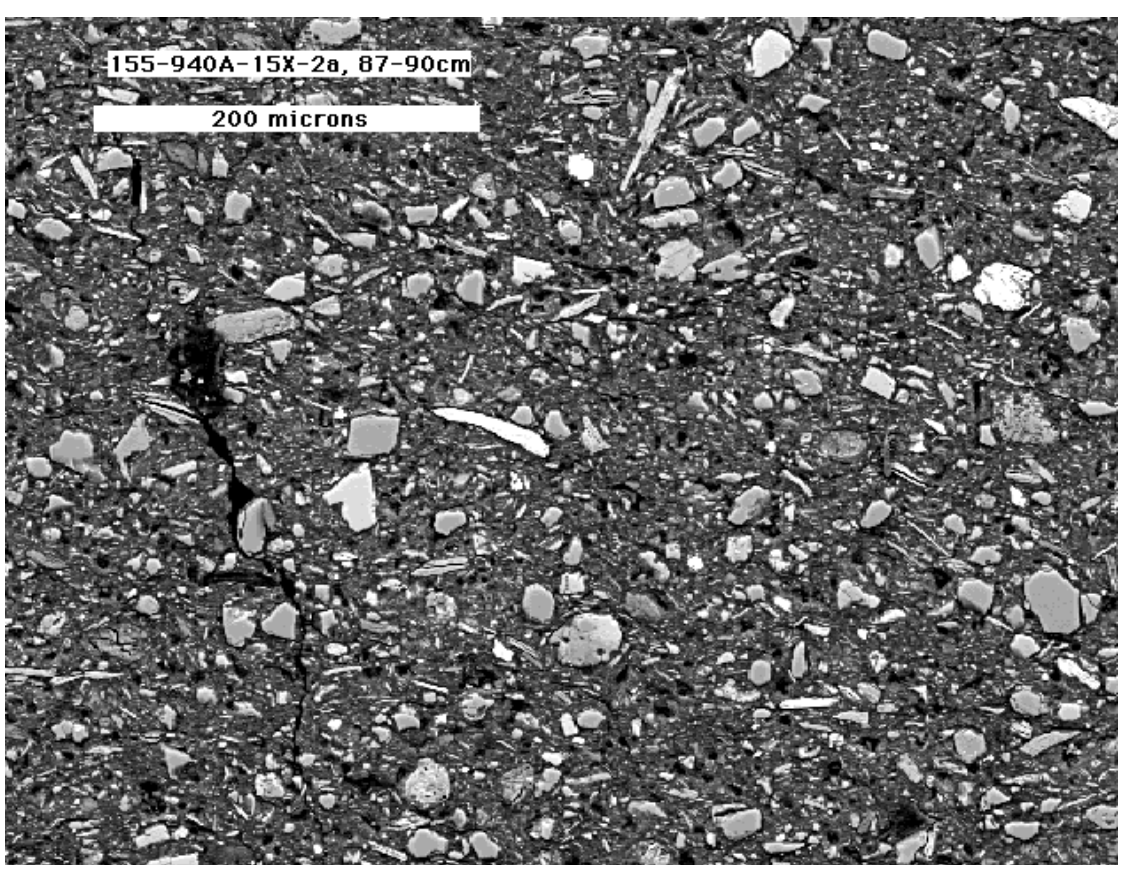

B

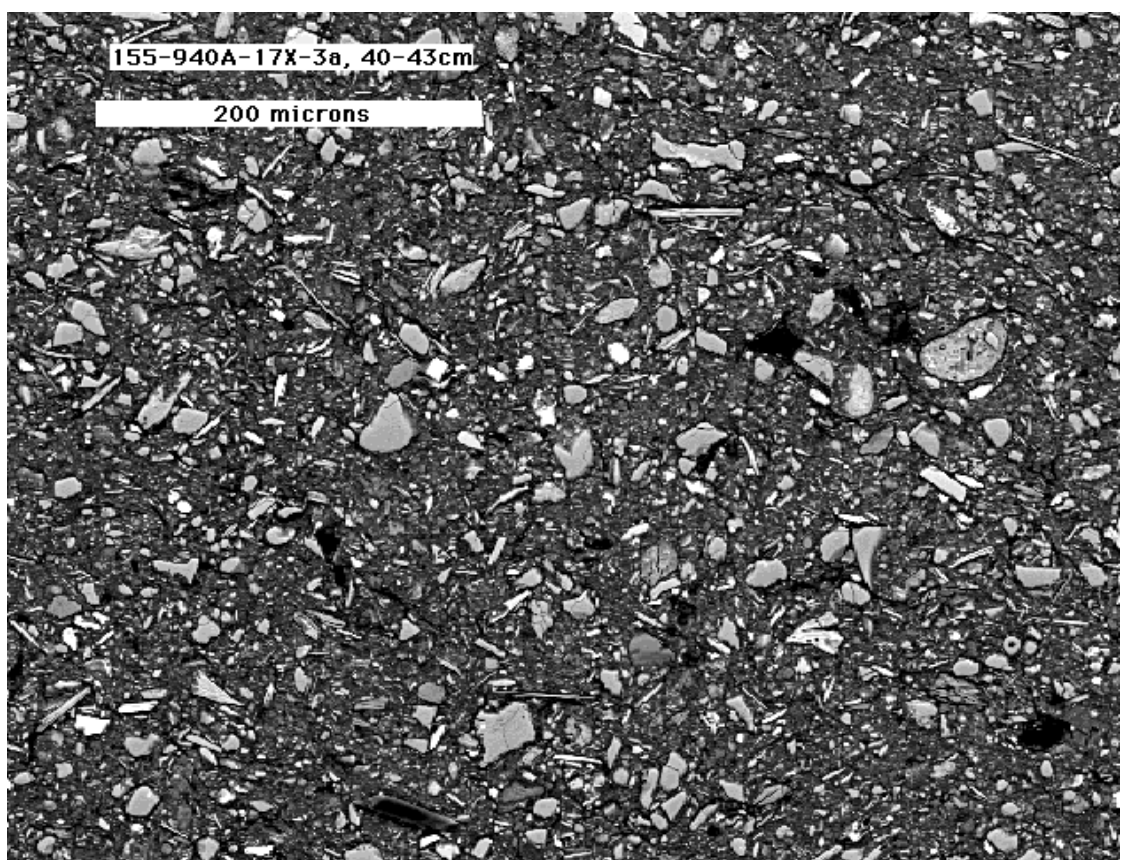

Figure 10. A. BSE image of Sample 155-940A-15X2A, $87-90 \mathrm{~cm}$ (125.67 mbsf). Note the homogeneous appearance and that the orientation and arrangement of grains reveal no lamination or planar fabric. The sediment also appears poorly sorted. B. BSE image of Sample 155-940A-17X-3A, 40-43 $\mathrm{cm}$ (146 mbsf). Note the homogeneous appearance, poor sorting, and that the orientation and arrangement of grains reveals no planar fabric. were observed. Matrix porosity is also lower at Site $946, \sim 2 \%-3 \%$ lower than in Hole 940, in the upper $150 \mathrm{~m}$ of section and does not approach as closely to the values in Hamilton's in situ porosity curve. These lower values may result from lower percentages of grains observed in the BSE images. Although Site 946 may be more sand-rich (see Manley et al., this volume), it appears that the mud-rich intervals (those with the best core recovery) are less silty and sandy than at Site 940 as the images suggest. The relatively lower values therefore observed in matrix porosity in the upper $150 \mathrm{mbsf}$ indicate that higher rates of compaction (or just more compaction) may have occurred at Site 946 . At depths below 150 mbsf, matrix porosity at both sites appears to agree with the values predicted by Hamilton's in situ curve. 
C

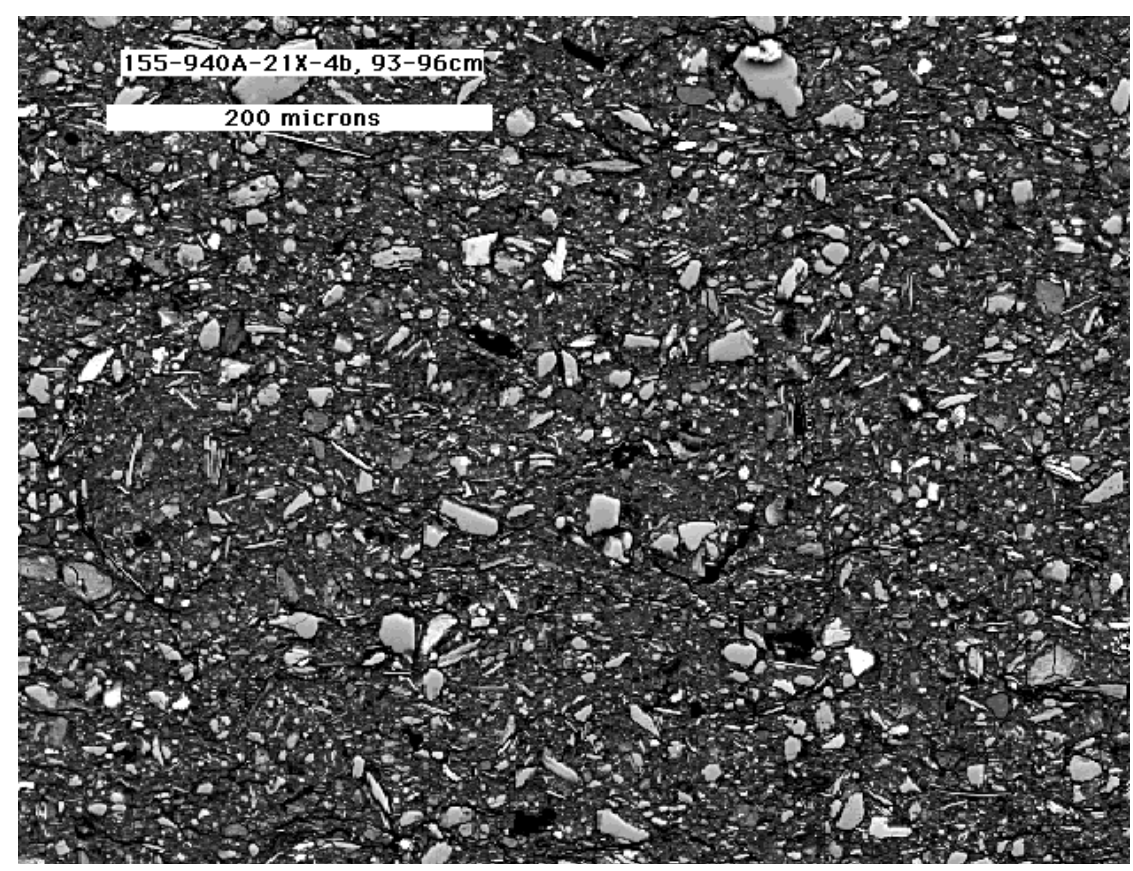

Figure 10 (continued). C. BSE image of Sample 155940A-21X-4B, 93-96 cm (186.53 mbsf), displays a faint planar fabric as indicated by flat- or planar-shaped grains that have become oriented parallel to bedding and may be a result of burial compaction.
Hole 940A compressional wave velocity (wireline log in situ values) closely match with Hamilton's (1979) instantaneous compressional wave velocity values derived for terrigenous sediments (siltclays, turbidites, mudstone-shales), and suggest that the sediments there are relatively homogeneous. Variability in velocity is significantly greater at Hole 946A. A least-squares regression fit to the velocity data for Hole $946 \mathrm{~A}$ reveals velocities generally higher $(\sim 50 \mathrm{~m} /$ s) than predicted by Hamilton (Fig. 18). This suggests that either the composition of the matrix is not as clay-rich (and, therefore, not as porous) as that predicted by Hamilton, or that some sand-rich intervals are grain supported rather than matrix supported at Site 946. A crossplot showing wireline compressional wave velocities vs. wireline density porosity for Holes 940A and 946A shows that the data lie within the bounds defined by the Wood (1941) and Wyllie et al. (1956) equations for clay-rich sediments (Fig. 19). It clearly shows the significantly higher variability in both the velocity and porosity domains at Site 946 and also suggests that the lithology at Site 946 is highly varied compared to the relatively homogeneous sedimentary section cored and logged at Site 940 . Matrix porosity vs. velocity values from Holes 940A and 946A reveal low variability for the most part and suggest that samples obtained from cores with relatively higher porosity and lower velocity are clay-rich cohesive sediments (i.e., more likely to be recovered in cores).

\section{CONCLUSIONS}

The downhole trends observed at Sites 940 and 946, as identified in scanning electron microscope BSE, index properties, and wireline log data are generally the same, but subtle differences are noticeable from one site to the other. Although there is no significant downhole trend in the relative percentages of grains and visible porosity, visual observation of images suggests that there is a progressive reorientation of grains downsection. A transitional boundary at $\sim 150 \mathrm{mbsf}$ is apparent at both sites and should be expected with increasing overburden pressure. Although visible pore-space values are low to begin with, there is no appreciable reduction in values observed. During normal compaction, porosity present as visible pores and as microporosity within the matrix should decrease with depth. The vari- ability in the relative percentages of grains at both sites appears to be more a function of lithologic variability controlled by changing sedimentary dynamics rather than being strictly a result of increased overburden above 150 mbsf.

Laboratory index porosity values obtained from Holes 940A and 946A appear to be in good agreement with wireline log-derived values. At Site 940, values lower than at Site 946 were observed for matrix porosity, and they may be attributed to a relatively silt-rich composition and texture of the matrix. A finer or more clay-rich matrix will tend to have higher porosity and perhaps values similar to Hamilton's predicted curve for deep sea terrigenous sediments. Because laboratory index and wireline log values fall below those predicted in situ values, it appears that the mud-rich Amazon Fan may be relatively silt-rich toward the middle and lower fan.

At Site 946, lower average grain percentages on the order of $2 \%-$ $3 \%$ lower than at Site 940 were observed. Matrix porosity is also $\sim 2 \%-3 \%$ lower at Site 946 in the upper $150 \mathrm{~m}$ of section, and values do not approach Hamilton's in situ porosity curve. These lower values may result from lower percentages of grains observed in the BSE images. The lower values observed in matrix porosity in the upper 150 mbsf suggest more extensive compaction at Site 946. At depths below 150 mbsf, matrix porosity at both sites appears to agree with the values predicted by Hamilton's in situ curve. Hole 940A compressional wave velocities closely agree with Hamilton's instantaneous compressional wave velocity values derived for terrigenous sediments and suggest that the sediments there are relatively homogeneous. The variability in compressional wave velocity is significantly greater at Hole 946A, and indicates velocities generally higher $(\sim 0.045 \mathrm{~km} / \mathrm{s})$ than predicted by Hamilton, thus suggesting that either the composition of the matrix is not as clay-rich, or that some sandrich intervals are grain-supported rather than matrix-supported.

A crossplot showing wireline compressional wave velocities vs. wireline density porosities for Holes 940A and 946A clearly shows the significantly higher variability in both the velocity and porosity domains at Site 946 and suggests that the lithology at Site 946 is highly varied compared to the relatively homogeneous sedimentary section cored and logged at Site 940. In general, these muds are matrixsupported, and therefore velocity is controlled by the matrix, not the grains. What is controlling the variability observed at Site 946 may 
A

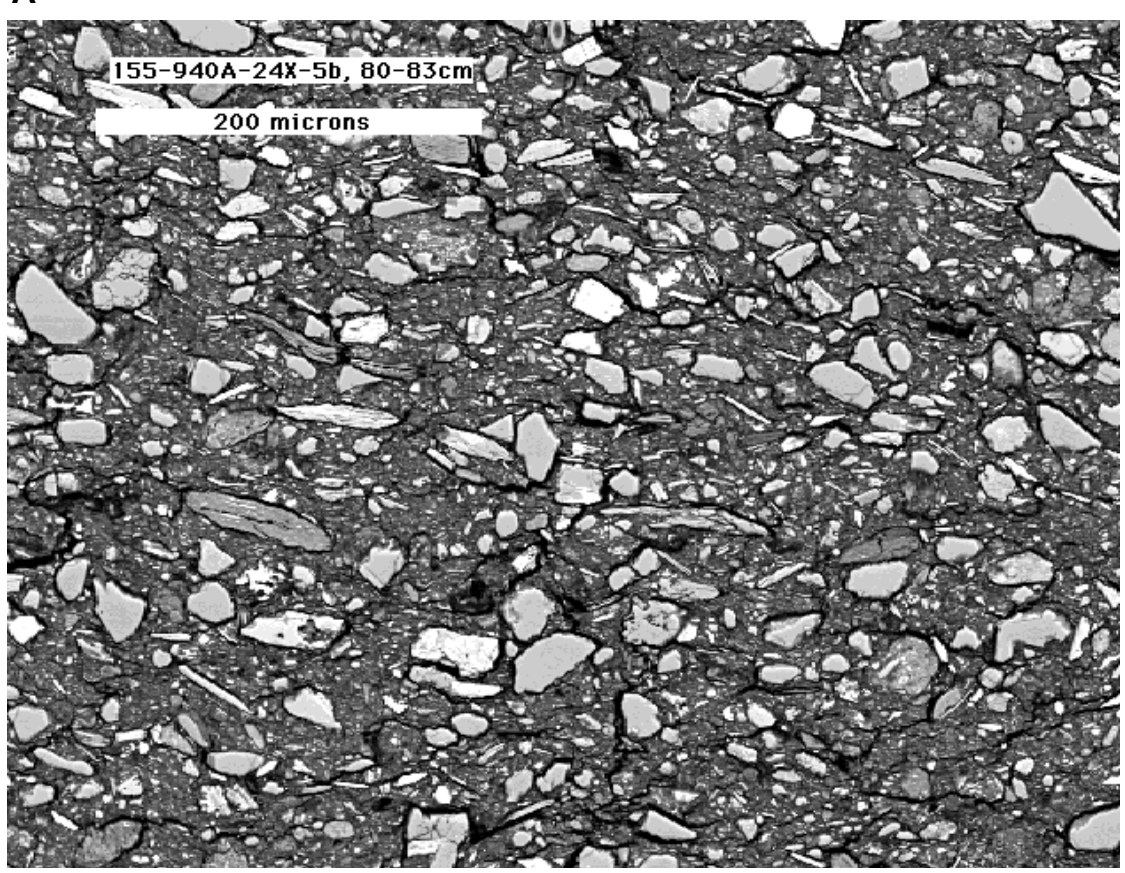

Figure 11. A. BSE image of Sample 155-940A-24X5B, 80-83 cm (216.8 mbsf), a well-defined planar fabric shown by rectangular to flat grains oriented parallel to bedding. The dark elements represent visible pore spaces mainly represented by cracks or the parting of matrix around the grains. B. Binary image of Sample 155-940A-24X-5B, 80-83 cm (216.8 mbsf), outlines cracks or the parting of matrix around grains.

\section{B}

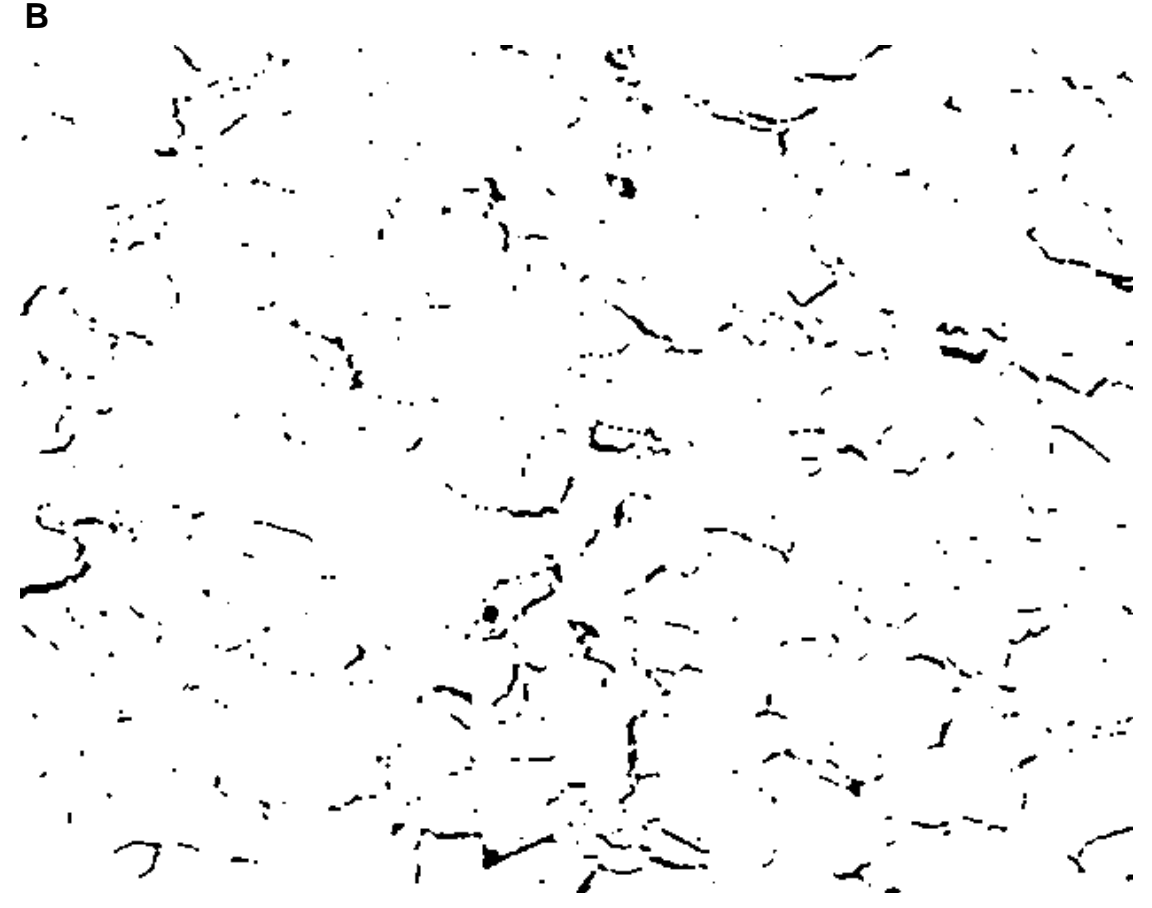

be the composition of the clay matrix. For example, variability between clay-rich vs. silt-rich matrixes may shed clues on changes in sedimentary dynamics with time and may also provide a climate or provenance change signal.

\section{ACKNOWLEDGMENTS}

This work was supported by JOI-USSSP grant $155-20849 \mathrm{~b}$ and NSF grant OCE-9503352. I thank the crew of the JOIDES Resolution for the successful results obtained from drilling the Amazon Fan and R. Wilkens for helpful comments and advice. Reviews by Donn S.
Gorsline and an anonymous reviewer improved the manuscript. This is SOEST contribution No. 4482.

\section{REFERENCES}

Bouma, A.H., Stelting, C.E., and Coleman, J.M., 1985. Mississippi Fan, Gulf of Mexico. In Bouma, A.H., Normark, W.R., and Barnes, N.E., (Eds.), Sumarine Fans and Related Turbidite Systems: New York (Springer-Verlag), 143-150.

Carneiro de Castro, J., Miura, K., and Estrella-Braga, J.A., 1978. Stratigraphic and structural framework of the Foz do Amazonas Basin. Proc. 10th Annu. Offshore Technol. Conf., 3:1843-1847. 
Damuth, J.E., and Flood, R.D., 1985. Amazon Fan, Atlantic Ocean. In Bouma, A.H., Normark, W.R., and Barnes, N.E., (Eds.), Submarine Fans and Related Turbidite Systems: New York (Springer-Verlag), 97-106.

Damuth, J.E., Flood, R.D., Knowsmann, R.O., Belderson, R.H., Gorini, M.A., 1988. Anatomy and growth patterns of Amazon deep-sea fan as revealed by long-range side-scan sonar (GLORIA) and high-resolution seismic studies. AAPG Bull., 72:885:911

Ferrell, R.E., Arman, A., and Grosch, J.F., 1989. X-ray radiographic investigation of perchloroethylene migration at Livingston derailment site. ASTM Geotech. Test. J., 12:119-125.

Ferrell, R.E., Jr., and Carpenter, P.K., 1991. Microtexture and microchemistry of clay-rich sediments. In Bennett, R.H., Bryant, W.R., and Hulbert, M.H. (Eds.), Microstructure of Fine-Grained Sediments, From Mud to Shale: New York (Springer-Verlag), 297-301.

Flood, R.D., Piper, D.J.W., and Shipboard Scientific Party, 1995. Introduction. In Flood, R.D., Piper, D.J.W., Klaus, A., et al., Proc. ODP, Init. Repts., 155: College Station, TX (Ocean Drilling Program), 5-16.

Hamilton, E.L., 1979. Sound velocity gradients in marine sediments. $J$. Acoust. Soc. Am., 65:909-922.

_ 1976. Variations of density and porosity with depth in deep-sea sediments. J. Sediment. Petrol., 46:280-300.

Kolla, V., and Coumes, F., 1985. Indus Fan, Indian Ocean. In Bouma, A.H., Normark, W.R., and Barnes, N.E., (Eds.), Sumarine Fans and Related Turbidite Systems: New York (Springer-Verlag), 129-136.

Manley, P.L., and Flood, R.D., 1988. Cyclic sediment deposition within the Amazon deep-sea fan. AAPG Bull., 72:912-925.

Mutti, E., and Normark, W.R., 1987. Comparing examples of modern and ancient turbidite systems: problems and concepts. In Leggett, J.K., and Zuffa, G.G., (Eds.), Marine Clastic Sedimentology: Concepts and Case Studies: London (Graham and Trotman), 1-38.

, 1991. An integrated approach to the study of turbidite systems. In Weimer, P., and Link, M.H., (Eds.), Seismic Facies and Sedimentary Processes of Submarine Fans and Turbidite Systems: New York (SpringerVerlag), 75-106.

Normark, W.R., 1978. Fan Valleys, channels, and depositional lobes on modern submarine fans-characters for recognition of sandy turbidite environments. AAPG Bull., 62:912-931.

Potter, P.E., Maynard, J.B., and Pryor, W.A., 1980. Sedimentology of Shale: New York (Springer-Verlag).
Pye, K., and Krinsley, D.H., 1984. Petrographic examination of sedimentary rocks in the SEM using backscattered electron detectors. J. Sediment. Petrol., 54:877-888.

Reynolds, S., and Gorsline, D.S., 1991. Silt microfabric of detrital, deep sea mud(stone)s (California Continental Borderland) as shown by backscattered electron microscopy. In Bennett, R.H., Bryant, W.R., and Hulbert, M.H. (Eds.), Microstructure of Fine-Grained Sediments, From Mud to Shale: New York (Springer-Verlag), 203-211.

Schlumberger, 1989. Log Interpretation Principles/Applications: Houston (Schlumberger Educ. Services).

Serra, O., 1984. Fundamentals of Well-Log Interpretation (Vol. 1): The Acquisition of Logging Data: Dev. Pet. Sci., 15A: Amsterdam (Elsevier).

Shipboard Scientific Party, 1995a. Leg synthesis. In Flood, R.D., Piper, D.J.W., Klaus, A., et al., Proc. ODP, Init. Repts., 155: College Station, TX (Ocean Drilling Program), 17-21.

1995b. Site 940. In Flood, R.D., Piper, D.J.W., Klaus, A., et al., Proc. ODP, Init. Repts., 155: College Station, TX (Ocean Drilling Program), 463-501.

, 1995c. Site 946. In Flood, R.D., Piper, D.J.W., Klaus, A., et al., Proc. ODP, Init. Repts., 155: College Station, TX (Ocean Drilling Program), 657-693.

Tribble, J.S., and Wilkens, R.H., 1994. Microfabric of altered ash layers, ODP Leg 131, Nankai Trough. Clays Clay Miner., 42:428-436.

Wartel, S., Singh, S.P., and Faas, R.W., 1991. The nature and significance of gas-generated microvoids as "secondary" microfabric features in modern and Pleistocene marine and estuarine sediments. In Bennett, R.H., Bryant, W.R., and Hulbert, M.H. (Eds.), Microstructure of Fine-Grained Sediments, From Mud to Shale: New York (Springer-Verlag), 55-59.

Whitmarsh, R.B., Weser, O.E, and Ross, D.A., et al., 1974. Init. Repts DSDP, 23: Washington (U.S. Govt. Printing Office).

Wood, A.B., 1941. A Textbook of Sound: London (G. L. Bell).

Wyllie, M.R.J., Gregory, A.R., and Gardner, L.W., 1956. Elastic wave velocities in heterogeneous and porous media. Geophysics, 21:41-70.

Date of initial receipt: 4 December 1995

Date of acceptance: 29 July 1996

Ms 155SR-233

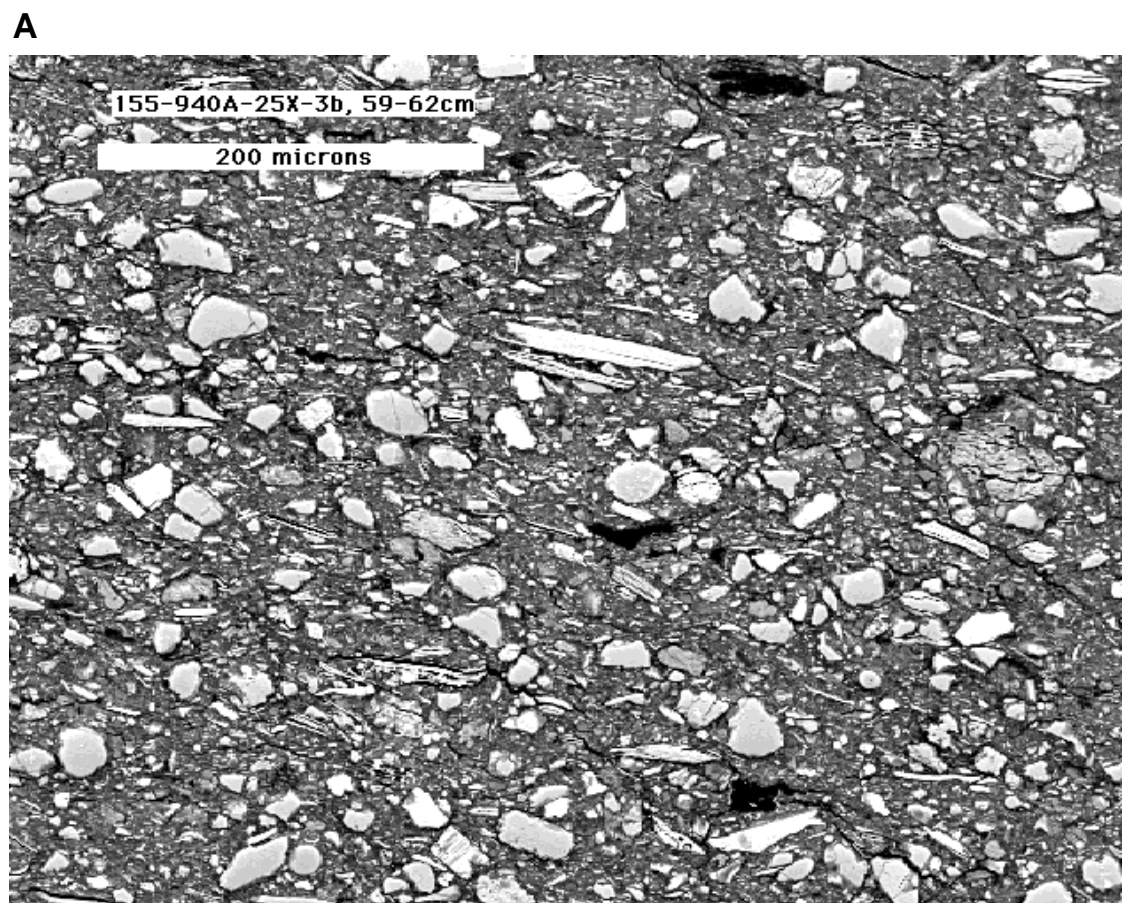

Figure 12. A. BSE image of Sample 155-940A-25X-3B, 59-62 cm (223.12 mbsf), reveals that the sediments are generally coarser grained and that the grains are oriented parallel to bedding. Visible pore space is of two kinds: cracks and partings around grains and along grains parallel to bedding, and small to large circular pores within the matrix. Grains are typically coarser, encompass a wide range in grain sizes from 10 to $70 \mu \mathrm{m}$, and represent $17 \%$ to $21 \%$ of the sediment. Spaces surrounding grains are most likely artifacts of the "decompaction" of matrix during retrieval. 

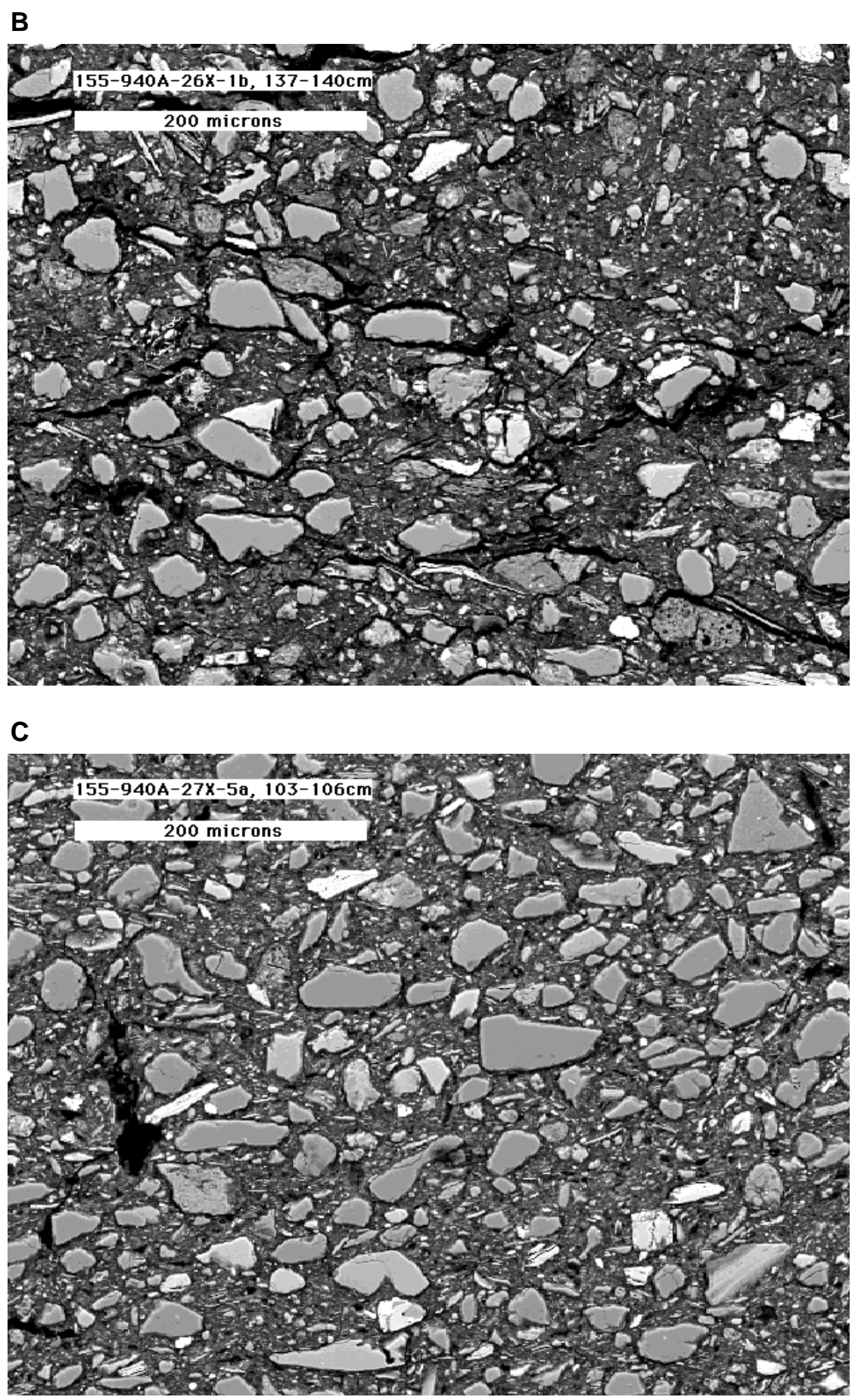

Figure 12 (continued). B. BSE image of Sample 155-940A-26X-1B, 137-140 cm (230.67 mbsf; see A). C. BSE image of Sample 155-940A-27X-5A, 103-106 cm (246.03 mbsf; see Fig. 12A). 


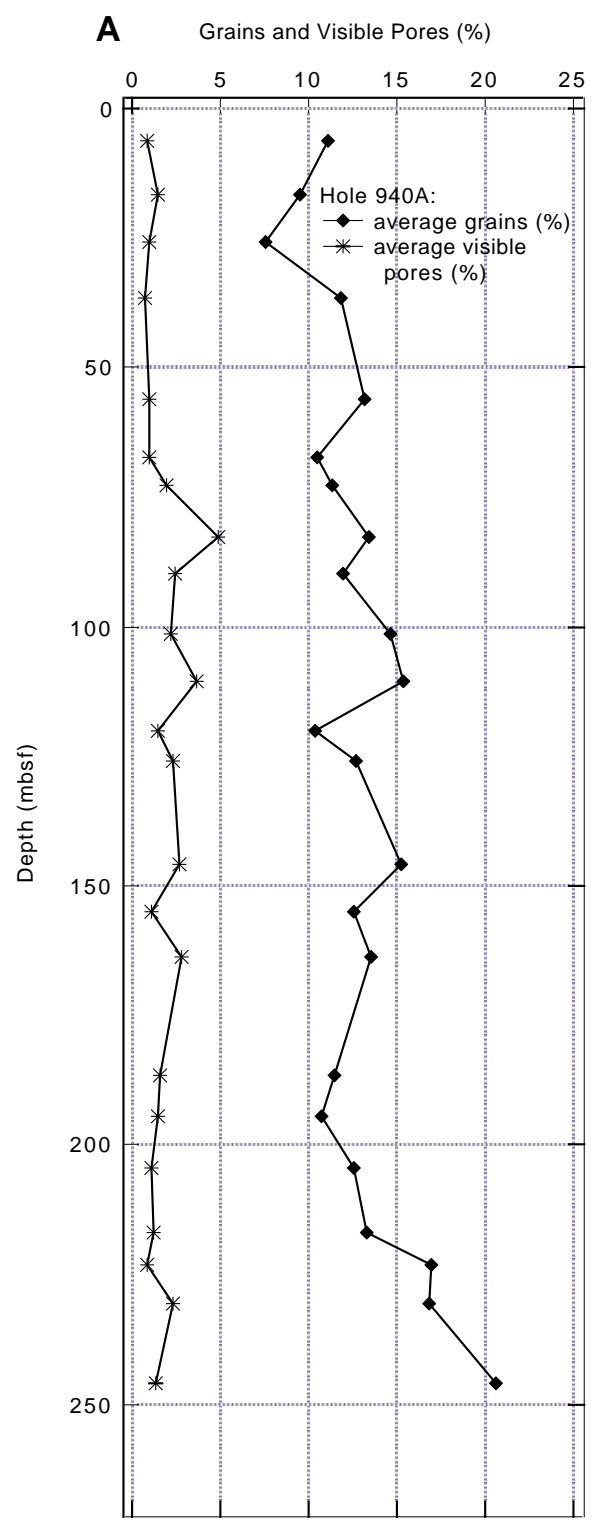

B

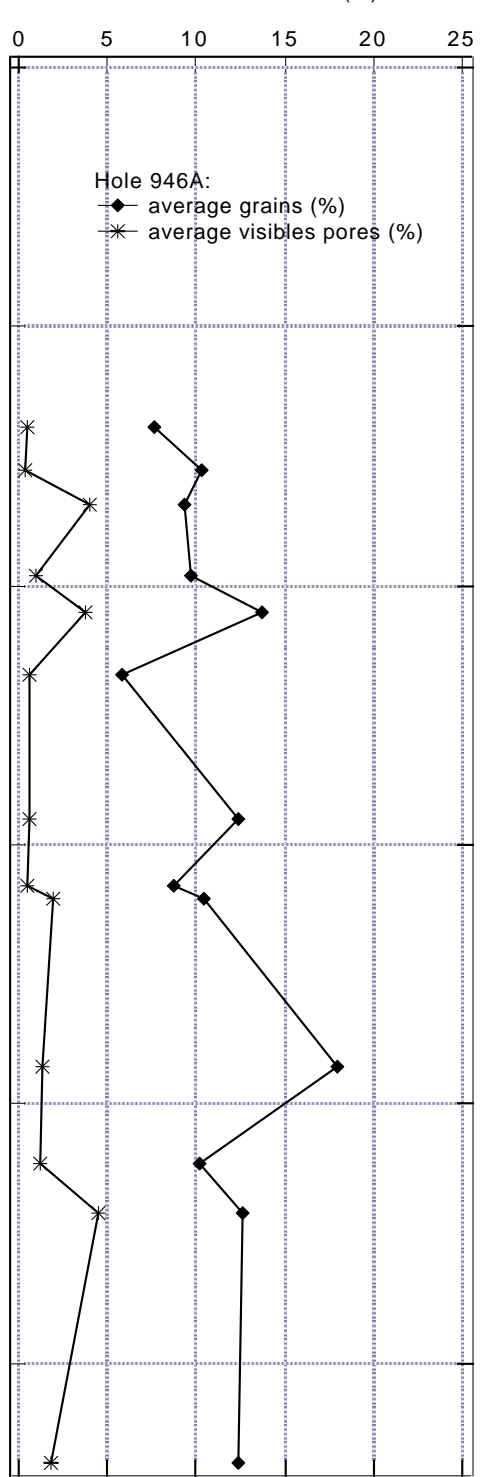

Figure 13. Downhole trends in percentage of grains and visible pore space for Holes (A) 940A and (B) 946A. 


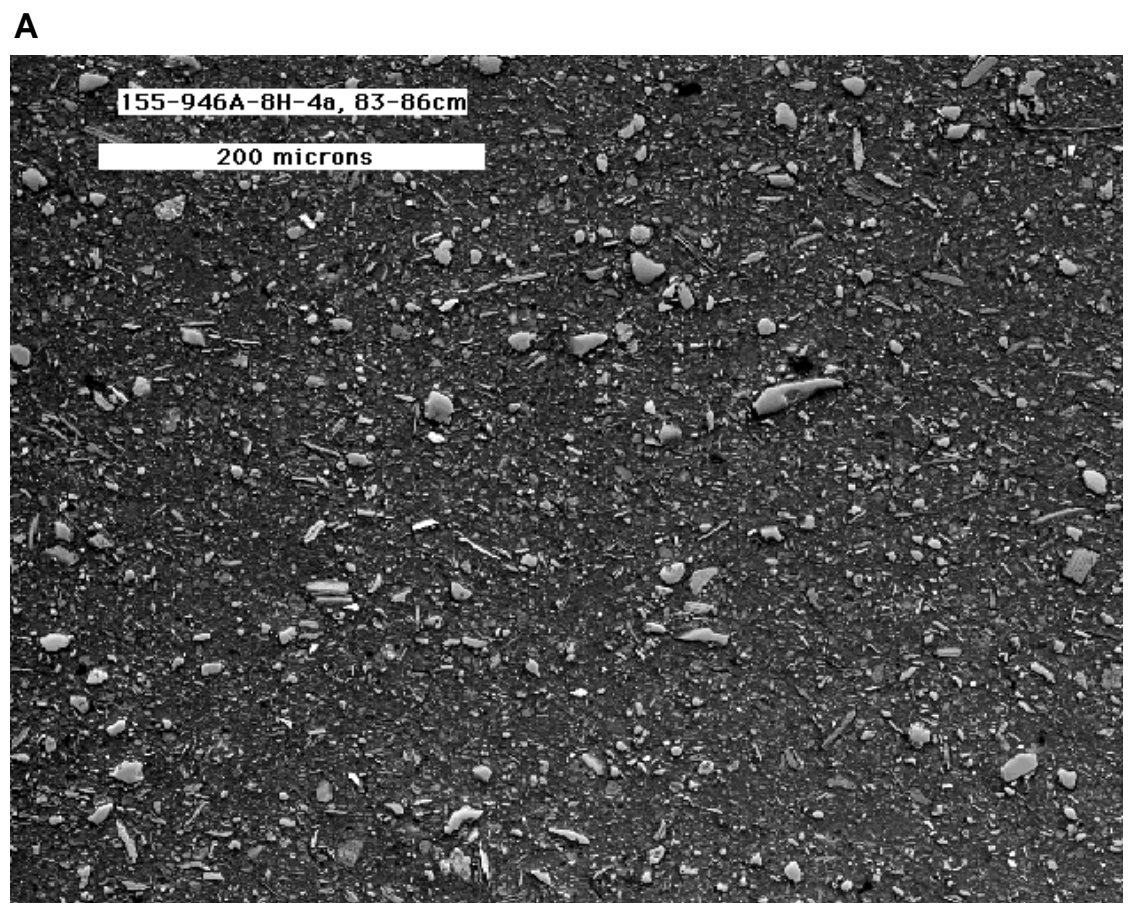

\section{B}

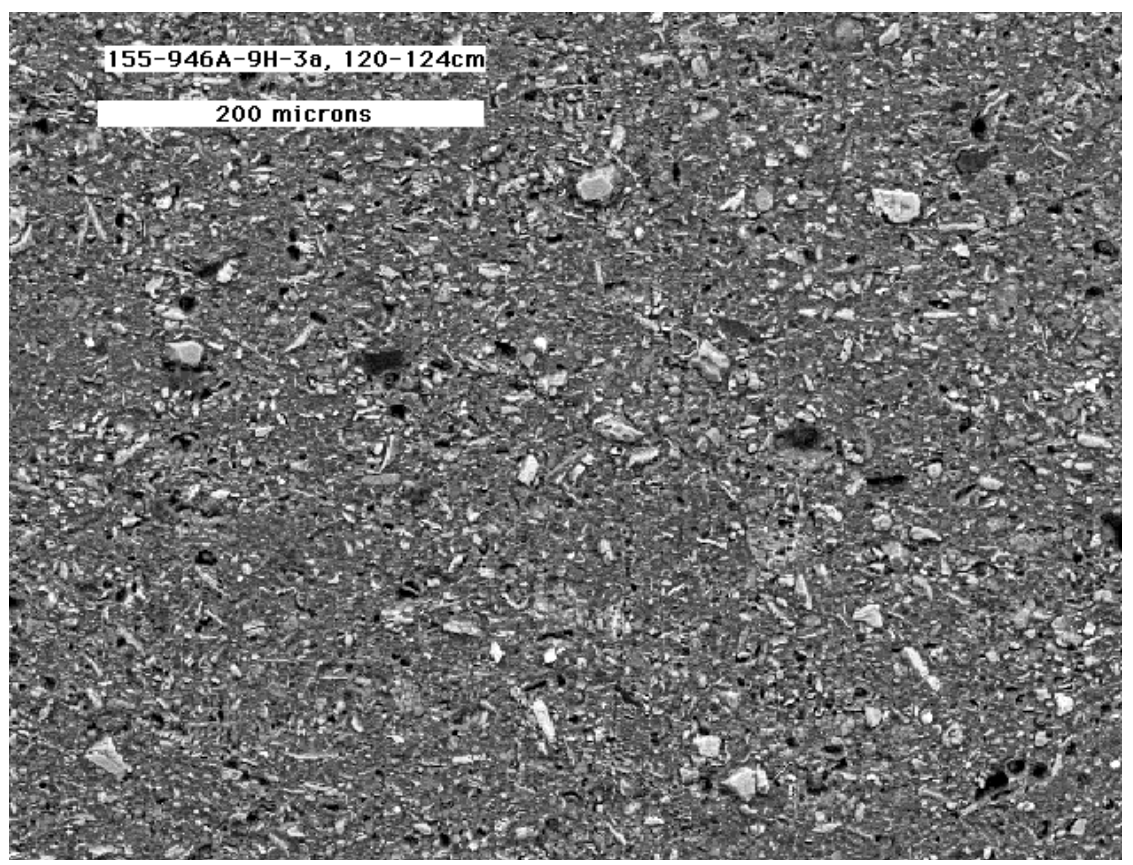

Figure 14. A. BSE image of Sample 155-946A-8H-4A, 83-86 cm (69.33 mbsf). B. BSE image of Sample 155-946A-9H-3A, $120-124 \mathrm{~cm}$ (77.7 mbsf). 


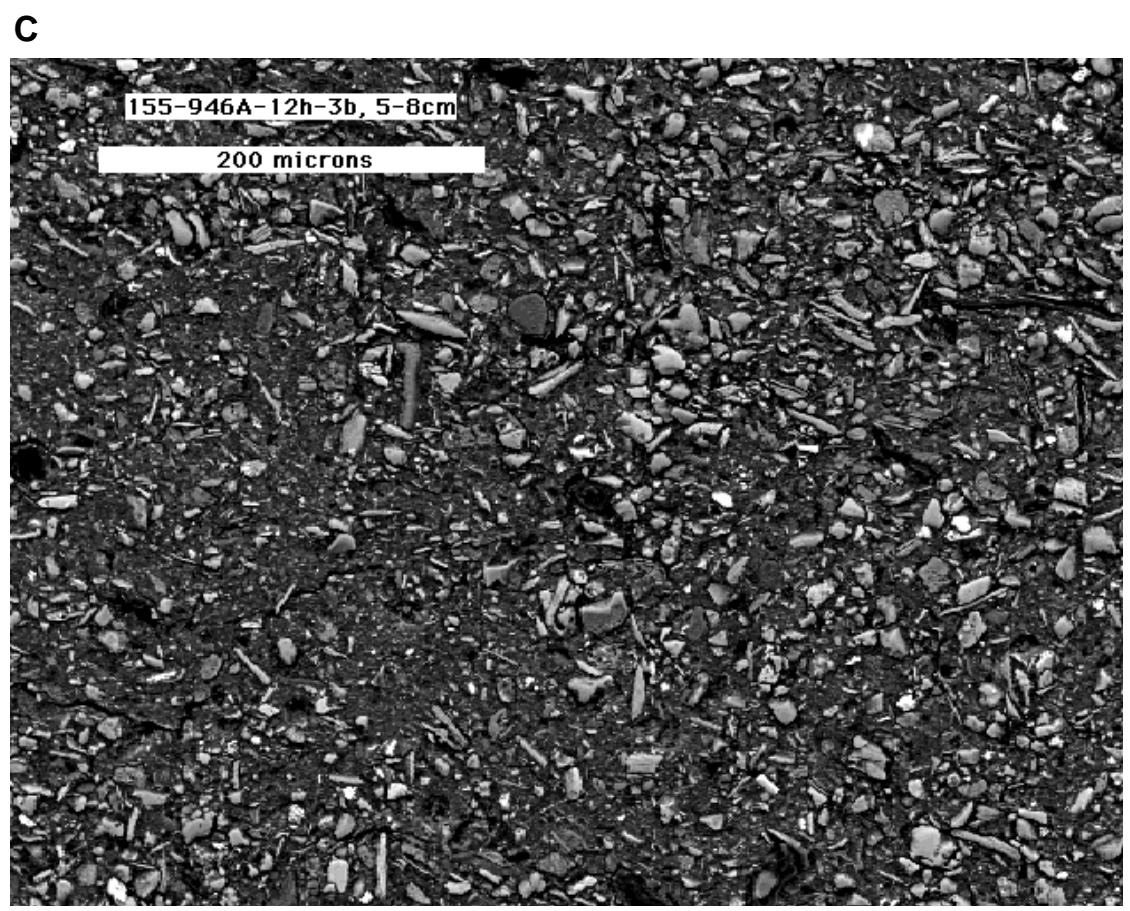

Figure 14 (continued). C. BSE image of Sample 155-946A-12H-3B, 5-8 cm (105.05 mbsf). All three images show comparable fabric arrangements to those observed in Samples 155-940-8H-5B, 135-138 cm (67.15 mbsf), and 11X-4C, 45-48 cm (89.62 mbsf; Figs. 9A, 9B), which are at similar depths below the seafloor. Note the generally finer grains found in these sediments. 


\section{A}

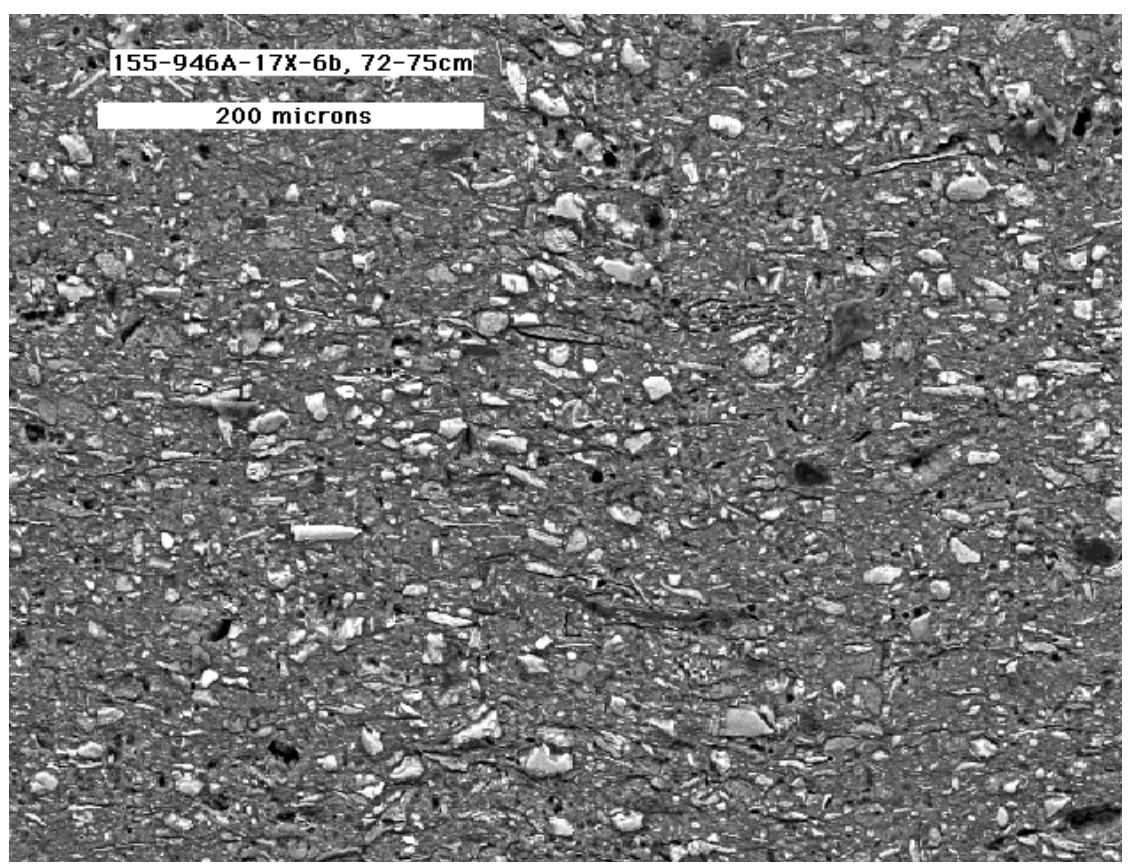

\section{B}

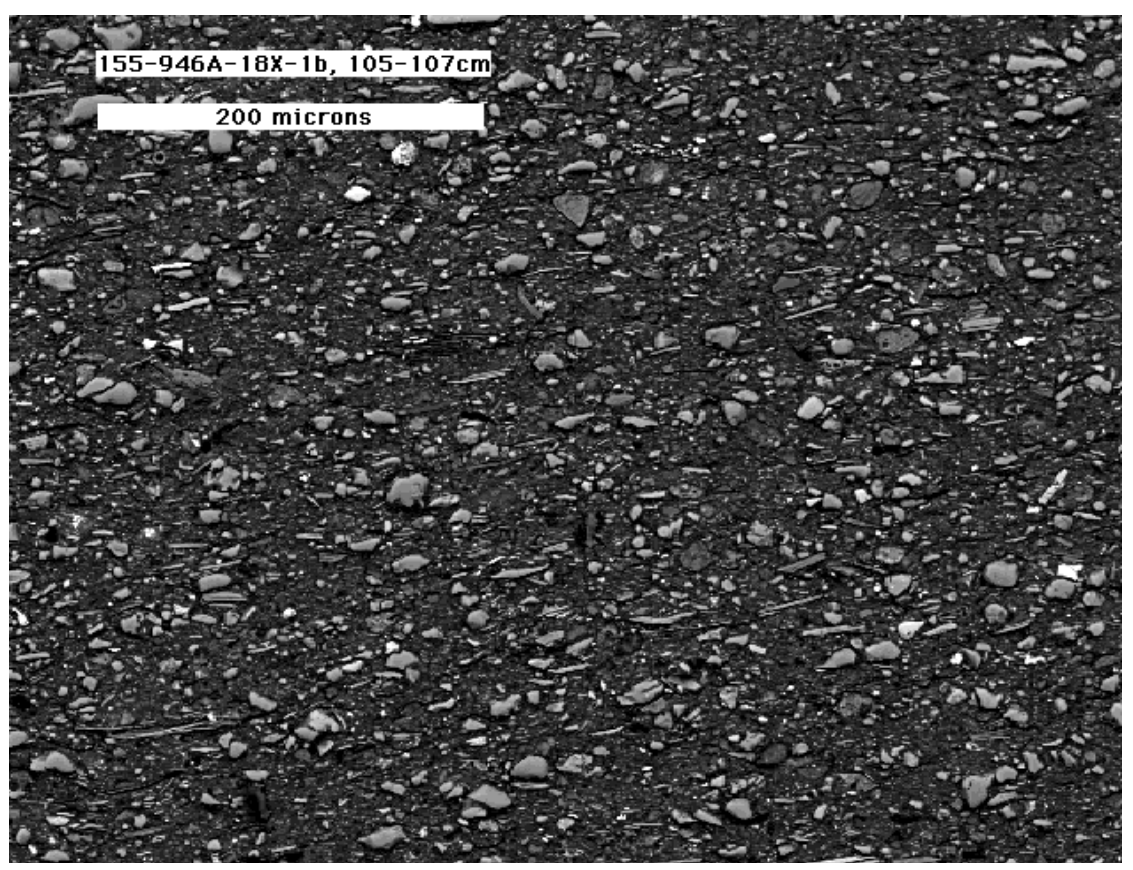

Figure 15. A. BSE image of Sample 155-946A-17X-6B, 72-75 cm (157.82 mbsf). B. BSE image of Sample 155-946A-18X-1B, 105-107 cm (160.25 mbsf). 

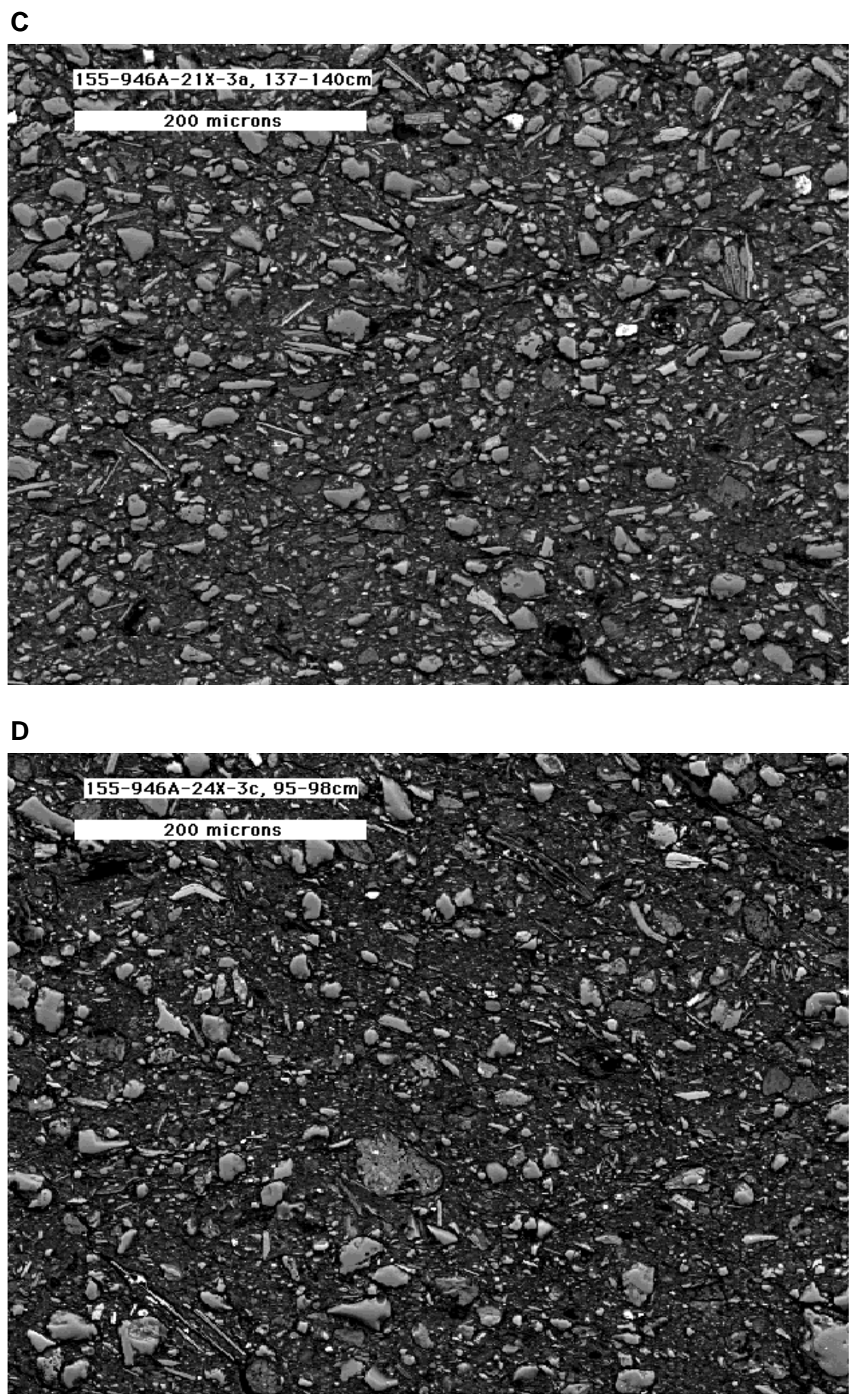

Figure 15 (continued). C. BSE image of Sample 155-946A-21X-3A, 137-140 cm (192.57 mbsf). D. BSE image of Sample 155-946A-24X-3C, 95-98 cm (221.05 mbsf). Note that the fabric arrangement is influenced by burial compaction, comparable to that observed in Samples 155-940A-17X-3A, 40-43 cm (146 mbsf), 21X-4B, 93-96 cm (186.53 mbsf), 24X-5B, 80-83 cm (216.8 mbsf), and 25X-3B, 59-62 cm (223.12 mbsf) in Figures 10B, 10C, 11A, and 12A. All are at similar depths below the seafloor. Again, note the generally finer grains found in these sediments. 
J.D. KRONEN, JR

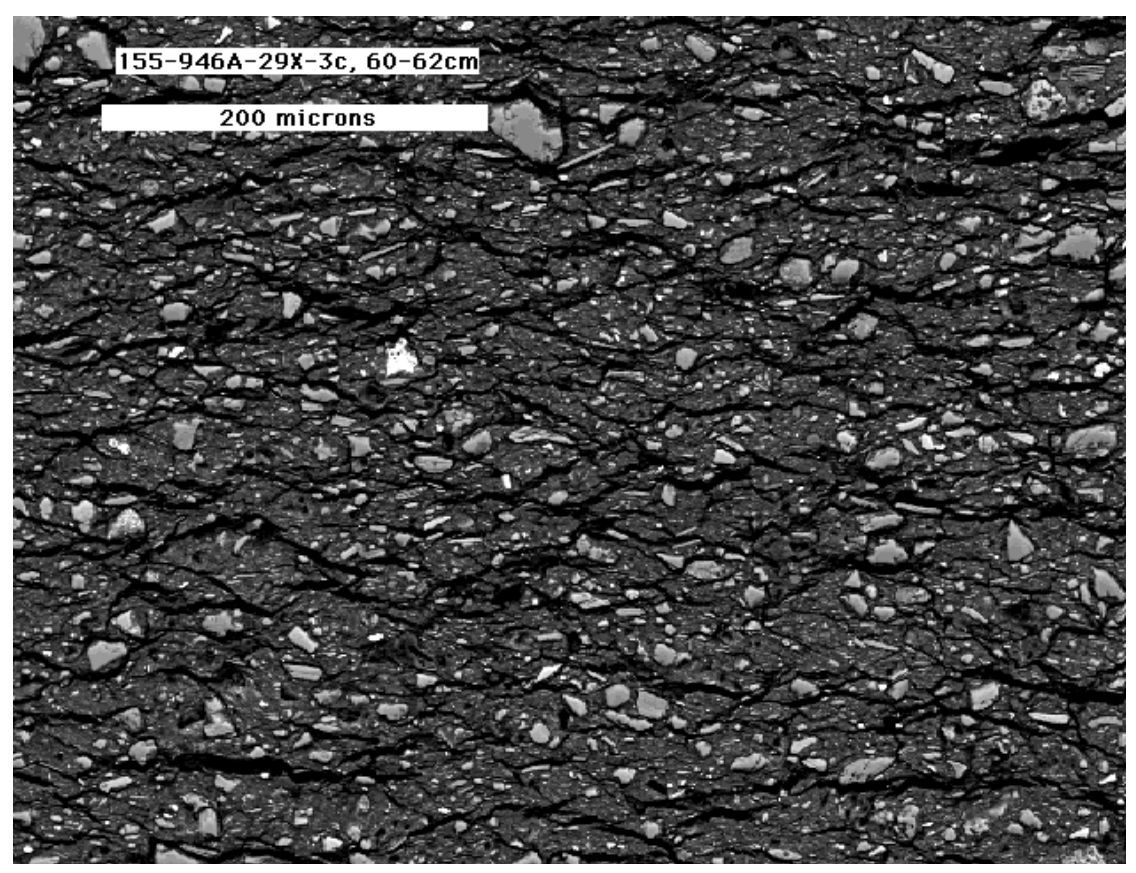

Figure 16. BSE image of Sample 155-946A-29X-3C, 60-62 cm (269 mbsf), displays evidence of further effects of compaction as grains are oriented parallel to bedding and cracks, suggesting that grains have been realigned. 


\section{A}

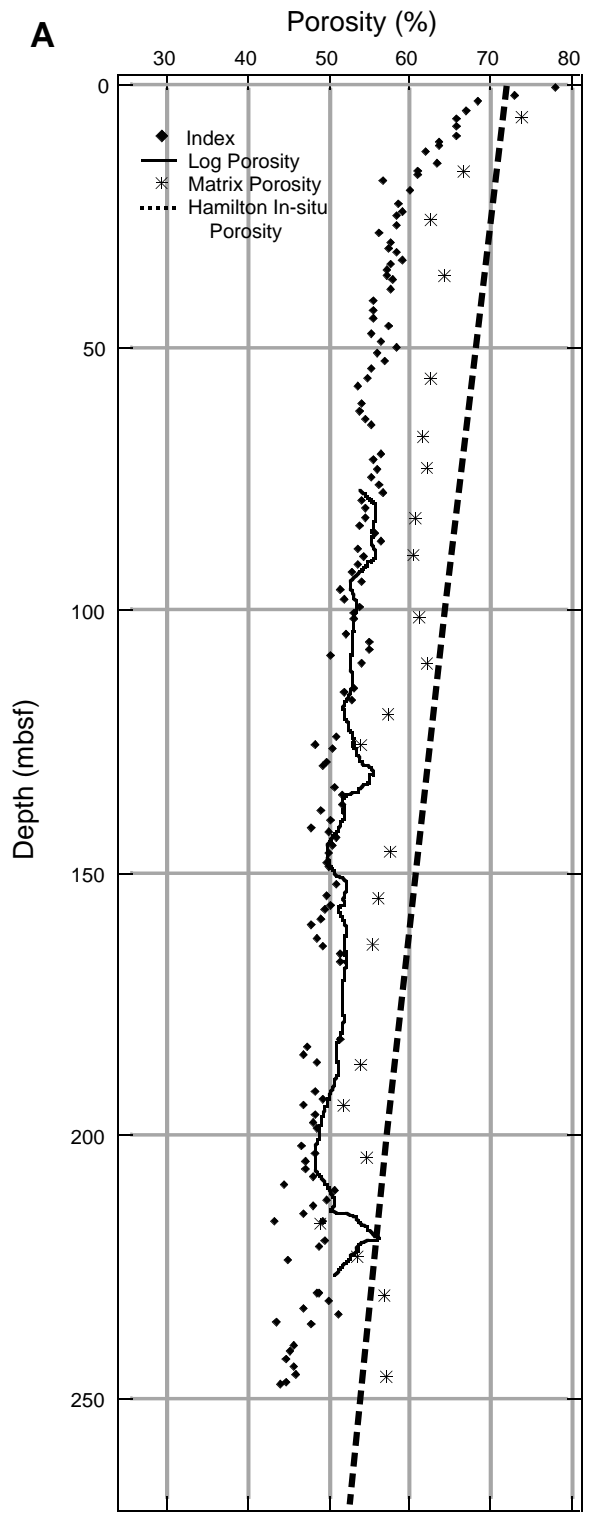

B

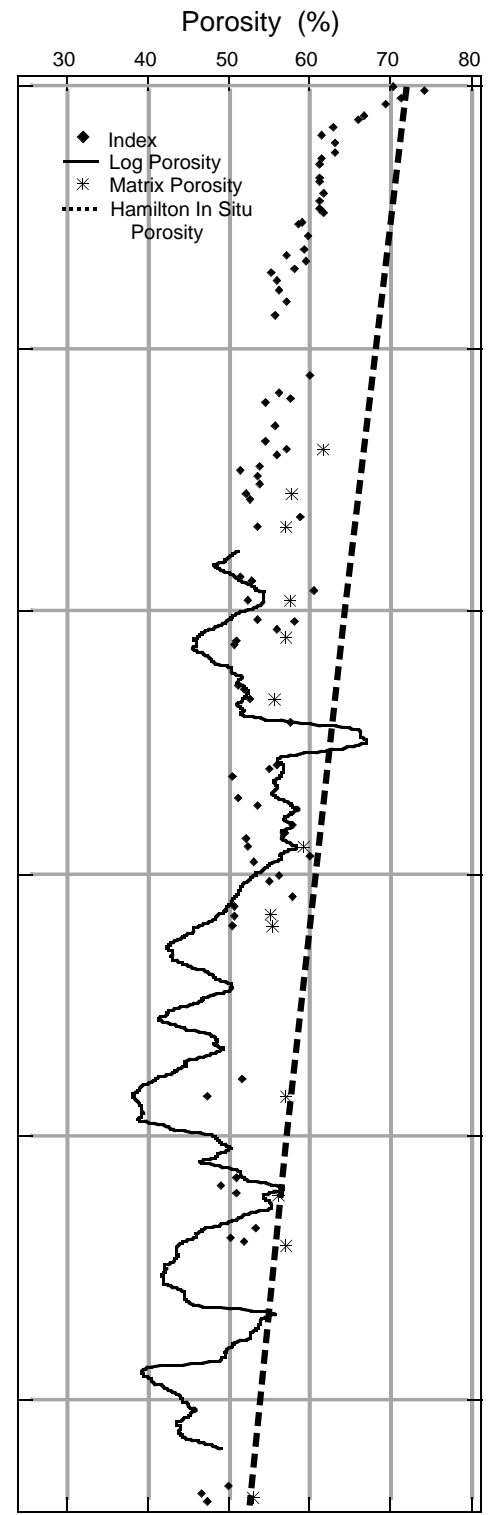

Figure 17. Downhole trends in wireline, laboratory, and matrix porosity for Holes (A) 940A and (B) 946A. An in situ curve of Hamilton (1976) is shown for comparison. Wireline density porosity data have been smoothed with a 5-m window. 


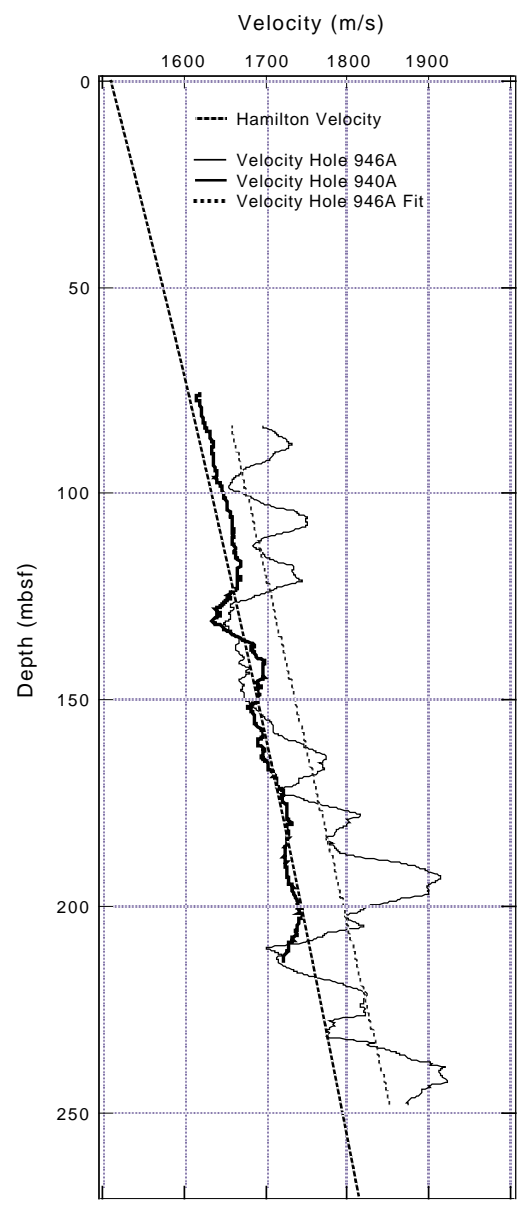

Figure 18. Downhole trends in wireline compressional wave velocity for Holes 940A and 946A. An in situ curve of Hamilton (1979) is shown for comparison.

Figure 19. Cross plot of wireline compressional wave velocity and density porosity for Holes $940 \mathrm{~A}$ and 946A. Field of values for Hole 940A are outlined by dashed oval.

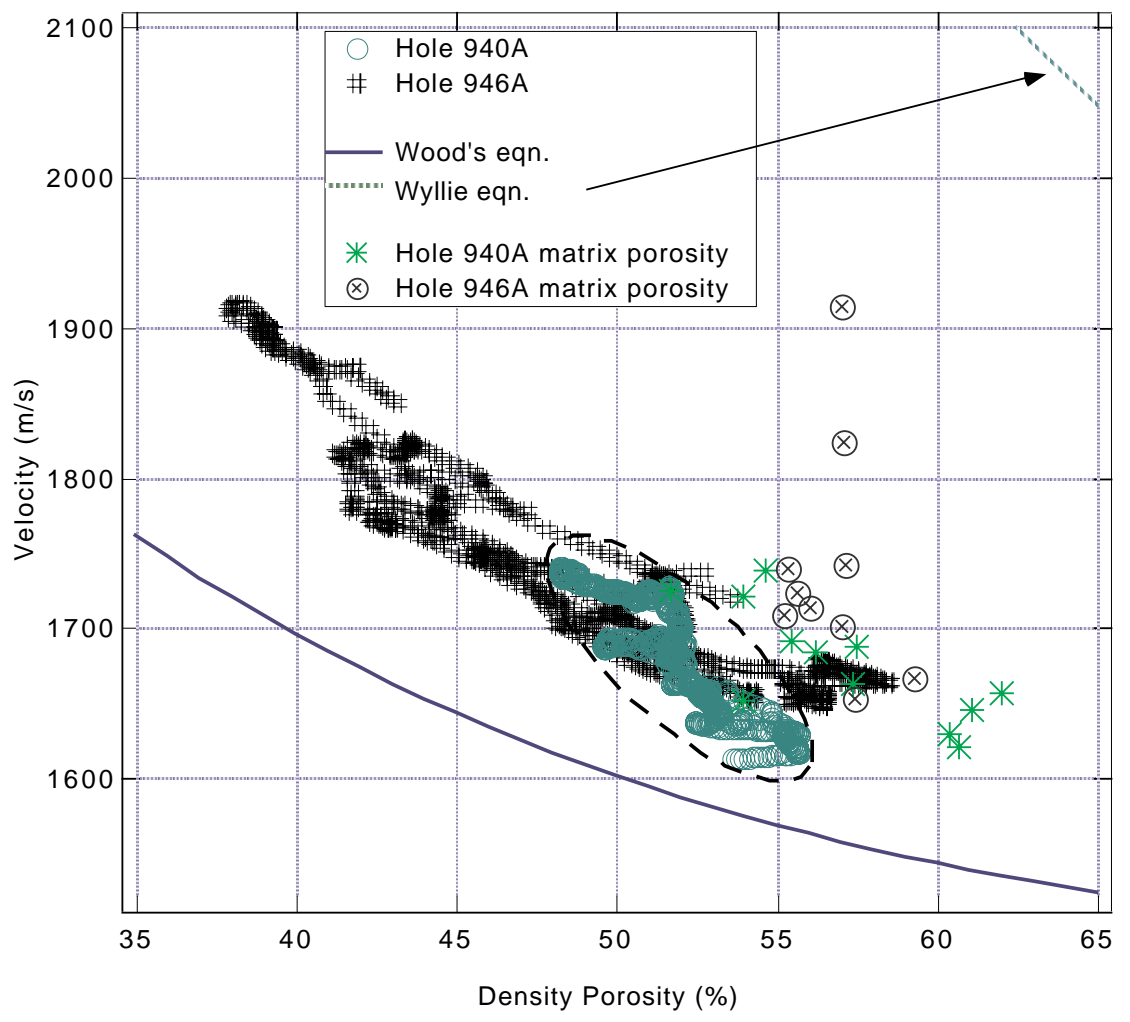

